\title{
Thin-bedded strata and tuning effect as causes of seismic data anomalies in the top part of the Cenomanian sandstone in the Grobla-Rajsko-Rylowa area (Carpathian foreland, Poland)
}

\author{
Paweł MARZEC and Kaja PIETSCH
}

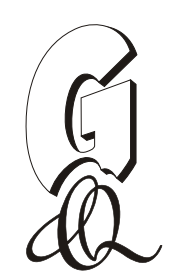

\begin{abstract}
Marzec P. and Pietsch K. (2012) - Thin-bedded strata and tuning effect as causes of seismic data anomalies in the top part of the Cenomanian sandstone in the Grobla-Rajsko-Rylowa area (Carpathian foreland, Poland). Geol. Quart., 56 (4): 691-710, doi: $10.7306 / \mathrm{gq} .1050$
\end{abstract}

\begin{abstract}
A high-amplitude anomaly in seismic signal, i.e. a bright-spot, which is the main direct hydrocarbon indicator, may also occur due to interference between the reflected signals from the top and base of a thin bed (the tuning effect). In such settings the main problem is to distinguish amplitude anomalies associated with lithological changes or changes in gas saturation from anomalies originating from the tuning effect. We provide a method of interpreting the composite seismic signal produced by the interference between reflections. Such reflections occur along the top of the Cenomanian sandstone in the area of the Grobla-Rajsko-Rylowa 3-D seismic dataset (southern Poland). The non-standard method presented here is based on interpretation of seismic data which was rotated by $270^{\circ}$. The results of seismic modelling were used to develop criteria for interpretation of such data. These criteria are based on the difference between information carried by the peak-to-trough amplitude and that by the total amplitude of rotated seismic data. The difference was used to define the transfer function and to remove the high-amplitude anomalies caused by the constructive interference between the reflected signals from the top and bottom of the thinning stratum. The final outcome of the study was a map showing the seismic amplitude response at the top Cenomanian reflector unaffected by the tuning effect. The map shows the extent of the area where high-amplitude anomalies do not correspond with changes in thickness and petrophysical parameters within the top part of the Cenomanian. These anomalies are caused by a lateral increase in thickness of the Turonian and/or an increase in the velocity within the bottom part of the Senonian (Coniacian) strata. The map can be used to determine precisely the boundaries of the Rajsko and Rylowa gas reservoirs as well as to locate the potential extension of the reservoir zone to the east of the Rylowa 6 borehole.
\end{abstract}

Pawet Marzec and Kaja Pietsch, Faculty of Geology Geophysics and Environmental Protection, Department of Geophysics, AGH University of Science and Technology, Mickiewicza 30,30-059 Kraków,Poland, e-mails: marzec@agh.edu.pl, pietsch@agh.edu.pl (received: April 17, 2012; August 30, 2012; first published online: December 11, 2012).

Key words: Poland, Carpathian foreland, Cenomanian, direct hydrocarbon indicators, seismic amplitude analysis, tuning effect.

\section{INTRODUCTION}

Analysis of direct hydrocarbon indicators (DHI), one of the basic methods of identifying reservoirs based on seismic data, can be very misleading when applied to thin-bedded strata. In such settings, seismic records depend not only on the lithology of reservoir strata, porosity and their gas saturation, but also on the thickness of the reservoir strata. High-amplitude anomalies in the seismic signal, which in many settings may be the main indicators of natural-gas-saturated pore spaces in reservoir rock (bright spots), may also originate from constructive interference between the reflected signals from the top and base of a thin bed, i.e. from the tuning effect. The interference between the reflected signals from the top and base of a bed may also lead to a decrease in amplitude, i.e. to destructive interference. The character of interference depends on the shape of seismic wavelets, the relation of the stratum thickness to the seismic wavelength, the relation between reflection coefficients associated with the top and base of the bed as well as on their polarization. The additional result of interference is change in the shape of the composite seismic signal (Widess, 1973; Kallweit and Wood, 1982).

Therefore, whenever amplitude analysis is used as the main hydrocarbon indicator or there is a possibility that the results of quantitative analysis (seismic inversion, amplitude versus offset - AVO) may have been significantly affected by the stratal geometry, it is necessary to assess the influence of signal inter- 
ference. The problem is particularly acute in areas where hydrocarbon reservoirs are formed by wedging beds or the thickness of the hydrocarbon-saturated zone is below the resolution of the seismic data. In such conditions, the composite seismic signal produced by the interference between reflections leads to an unreliable geological interpretation or even makes interpretation impossible. Therefore, it is necessary to recognize the representation of thinly bedded sequence on seismic data, and to propose a method which would offer a more reliable seismic-geological interpretation.

\section{GEOLOGICAL SETTINGS AND HYDROCARBON RESERVOIRS IN THE STUDY AREA}

The study focuses on the Cenomanian succession, which is a part of the Permo-Mesozoic sedimentary cover of the epiVariscan platform, i.e. the basement of the Miocene Carpathian Foredeep Basin (Fig. 1A; Oszczypko and Ślączka, 1989; Oszczypko et al., 2006). In the basement of the central part of the basin, to the east of Kraków, this succession forms an extension of the Cretaceous Miechów Synclinorium which dips towards the south beneath the Carpathian thrust belt (Fig. 1B). The Cenomanian succession comprises transgressive deposits which gradually filled the varied morphology of the top Jurassic surface formed by Early Cimmerian deformation and by subsequent erosion during the Early Cretaceous. The contemporary extent of the Cenomanian deposits (Fig. 1C) has mainly a depositional character and reflects the pre-Cenomanian palaeosurface (Jawor, 1973). In the axial parts of the sedimentary basin, the palaeodepressions are filled by poorly cemented glauconitic sandstones which are characterized by porosity of over $25 \%$ and permeability reaching 9 darcy. Their thickness locally reaches over $100 \mathrm{~m}$. In the transition zone, where their thickness ranges from 2 to $10 \mathrm{~m}$, their porosity is between 10 and $15 \%$ with permeability of up to 1 darcy. In the marginal zones, where the stratal thickness is less than $2.5 \mathrm{~m}$, the sandstones gradually pass into conglomerates with a porosity of a few percent and permeability ranging from 0 to several $\mathrm{mD}$ (Florek et al., 2006). Each of the subsequent Late Cretaceous transgressions had a slightly wider extent; Turonian carbonates and Senonian (Coniacian-Maastrichtian) marly limestones overlap the Lower Cenomanian, forming a seal for the reservoir rock. At the end of the Cretaceous, as a result of the widespread inversion of the Mid-Polish Trough, the Cretaceous sea withdrew from the study area. Following inversion-related uplift, the Upper Mesozoic succession was intensely eroded. Locally, fluvial erosion formed deep palaeovalleys (such as the Szczurowa palaeovalley) incised into the Upper Cretaceous strata and sometimes even reaching Jurassic strata. The Miocene sea entered the foreland following emplacement of the Carpathian thrust belt; it gradually filled depressions and troughs with Badenian deposits and levelled the palaeosurface (Florek et al., 2006; Oszczypko et al., 2006).

Three hydrocarbon accumulations have been discovered and documented within the Jurassic and Cenomanian successions in the study area, related to structural traps and lateral lithology and sedimentary facies changes (Florek et al., 2002).
The Grobla field is located in the western part of the study area. Hydrocarbons (oil and gas) are accumulated within the Cenomanian sandstones and conglomerates, whose total thickness decreases towards the west, and within the upper part of the Malm carbonate succession (Fig. 1B, C). The reservoir is sealed from the top by impermeable Turonian and Senonian deposits, and from the north and south by systems of faults. The Rajsko field is located in the central part of the study area where the Cenomanian sandstones have the greatest thickness. Here, gas is accumulated in its top section which is over ten metres thick. The reservoir is limited to the north-east and south-west by faults (Fig. 1B, C). The Rylowa field is located in the southeastern part of the study area (Fig. 1B, C). The trap has an anticlinal form with its axis oriented along a NW-SE direction (Jawor et al., 1997). As in the case of the Rajsko reservoir, it is additionally limited by fault zones. The sandstone thickness ranges between 37 and $59 \mathrm{~m}$, while the maximum thickness of the saturated zone documented by the Rylowa 5 borehole is $48.5 \mathrm{~m}$. The thickness of the Cenomanian sandstone decreases rapidly to a few metres towards the east of the field.

\section{SEISMIC RESULTS}

The area of research is covered by 3-D seismic surveys (Grobla-Uście Solne and Grobla Wschód-Rylowa) that were carried out by Geofizyka Kraków Ltd. in 1993 and 1996. These two surveys were re-processed to obtain a combined set of seismic measurements (Fig. 1C). The geophysical investigation over the subject area was not uniform in terms of location of boreholes and scope of logging, nor as regards the technology applied, that varied over the years of investigation.

Most boreholes are is located around the Grobla gas and oil reservoir. Unfortunately they were drilled mainly in the 1960's and 1970's when the scope of logging was limited. Boreholes in the other parts of the project area were completed in recent years and have provided a full set of downhole logging data.

The exact correlation of seismic records and geological logs from the investigation boreholes was obtained based on synthetic seismograms (system GeoGraphix, Landmark Graphics Corp.) by using the recorded and corrected DT curves, and, for the boreholes lacking acoustic profiles, the synthetic DTsyn. curves. In addition, the density curves (RHOB), neutron porosity curves (NTCN) were used as well as information on lithology and saturation.

Once correlated to geological profiles, the seismic data from the 3-D surveys at Grobla-Uście Solne and Grobla Wschód-Rylowa enabled identification and correlation of other seismic boundaries, of which the top of the Badenian evaporites (Mb2), and of the Chalk ( $\mathrm{Cr})$, Turonian (Crct), Cenomanian $(\mathrm{Crc})$ and Jurassic (J3) were the most important for further interpretation. A geologically interpreted seismic section along an arbitrary profile 1 is shown in Figure 2. It traverses the zone of Cenomanian truncation over Jurassic strata (western part of the Grobla area), then the zone of thick Cenomanian deposits with increased amplitudes at the Strzelce Wielkie 1 and Grobla Wschód boreholes and within the Rajsko reservoir (central part), then continues across the Rylowa 


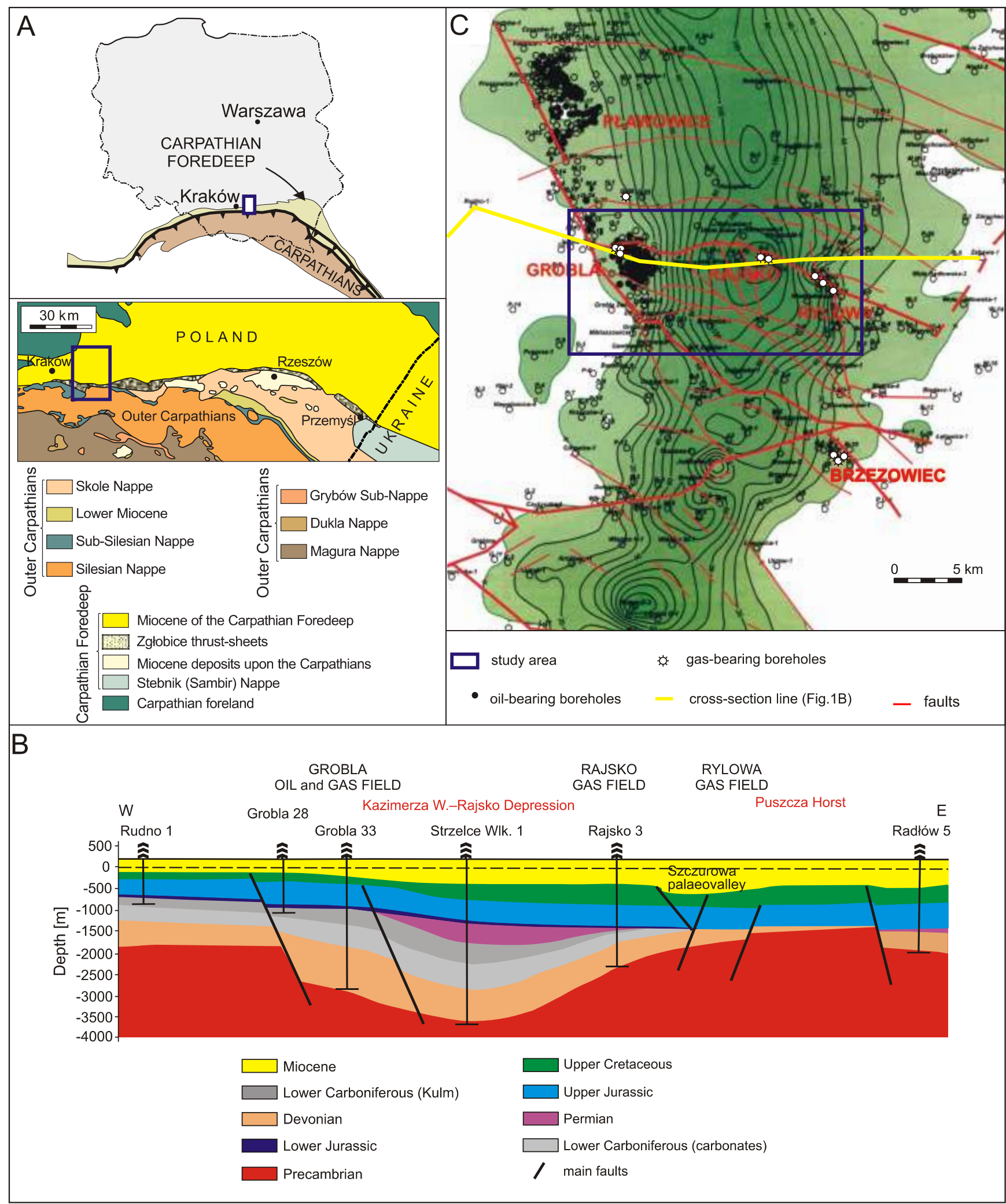

Fig. 1. Outline of the geology of the study area

A - location of research area within Poland and in the Carpathian Foredeep; $\mathbf{B}$ - geological cross-section through the study area; cross-section line is indicated in Figure 1C (after Florek et al., 2006); C - thickness map for the Cenomanian stratum in the area to the east of Kraków (after Baran et al., 1999) 


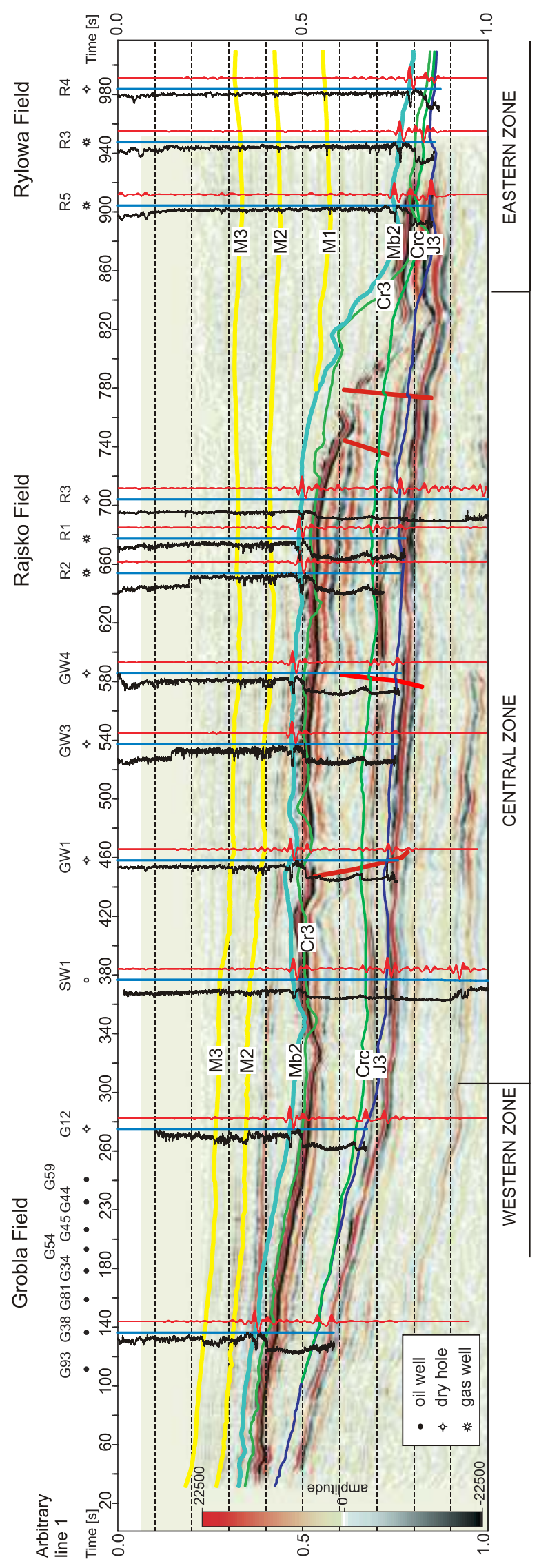

trench filled with Miocene deposits up to the Rylowa reservoir (eastern part). The section shows fault zones intersecting with both the Jurassic and Cretaceous deposits.

The results of attribute analysis are normally the basis for selecting prospective areas; in particular the analysis of amplitude anomalies that are in many cases the main indicators of gas saturation of the pore volumes. Saturation with gas, instead of with water, leads to apparent drop of seismic wave propagation velocity $(\mathrm{V})$ and density $(\rho)$ that in consequence appears as high contrast in acoustic impedance $(\mathrm{V} \rho)$ of the adjoining beds. Also, the reflection coefficient increases, hence the amplitude of wave reflected from the top of the zone saturated with gas (bright spot). In the research area only some of the boreholes were located using seismic amplitude anomalies.

Unfortunately, not all exploratory boreholes, designed using, data including reflection amplitude anomalies, proved the presence of hydrocarbon reservoirs. Figure 3 shows a horizon map of instantaneous amplitude along the top of the Cenomanian (Fig. 3A) as well as an arbitrary line 1 seismic section showing the same attribute (Fig. 3B). The presence of gas in the Rajsko (production the Rajsko 1 and 2 boreholes) and Rylowa (production the Rylowa 6, 5 and 3 boreholes) field corresponds with the presence of classic examples of bright spots on the horizon map as well as on the seismic section which display instantaneous amplitude (Fig. 3B, anomalies 5 and 8). The amplitude is, however, only locally increased in the Grobla oil reservoir (Fig. 3B, anomaly 1). During seismic data acquisition, production from this field had already ended (Karnkowski, 1999). A number of instantaneous amplitude anomalies are also apparent outside the area of proved HC accumulation, and the amplitude strength is as high as those associated with the proven accumulations. Without additional data, it is difficult to determine their origin. The lack of gas saturation in boreholes (such as Grobla Wschód 3 and 4, Górka 5 and Rylowa 10 boreholes) located in areas associated with the amplitude anomalies disqualifies them as bright spots, although the origin of strong amplitude in relation to adjacent areas has not been satisfactorily explained so far.

In order to determine the source of the anomalies based on the relations between reflections from the top of the Jurassic and the top of the Cenomanian succession, three zones, i.e. western, central and eastern, visible on the Grobla-Rajsko-Rylowa seismic line (Figs. 2 and 3B), have been analysed.

\section{WESTERN ZONE}

This zone covers an area (anomaly no. 1 on Fig. 3B) where the interference between the top and base of the Cenomanian sandstone wedge (tuning zone) has the main influence on the seismic amplitude. The extent of this zone is controlled strictly by the thickness of the Cenomanian succession and the parameters of the seismic signal. The dominant influence of reflection coefficient values, associated with the top and base of the Cenomanian succession in the tuning zone, is apparent on images showing the calibration of seismic data with borehole data using synthetic seismograms from the Grobla 44 boreholes (G44; Fig. 4A) and Grobla 12 (G12; Fig. 4B). Apart from high values of reflection coefficient values associated with the top and 


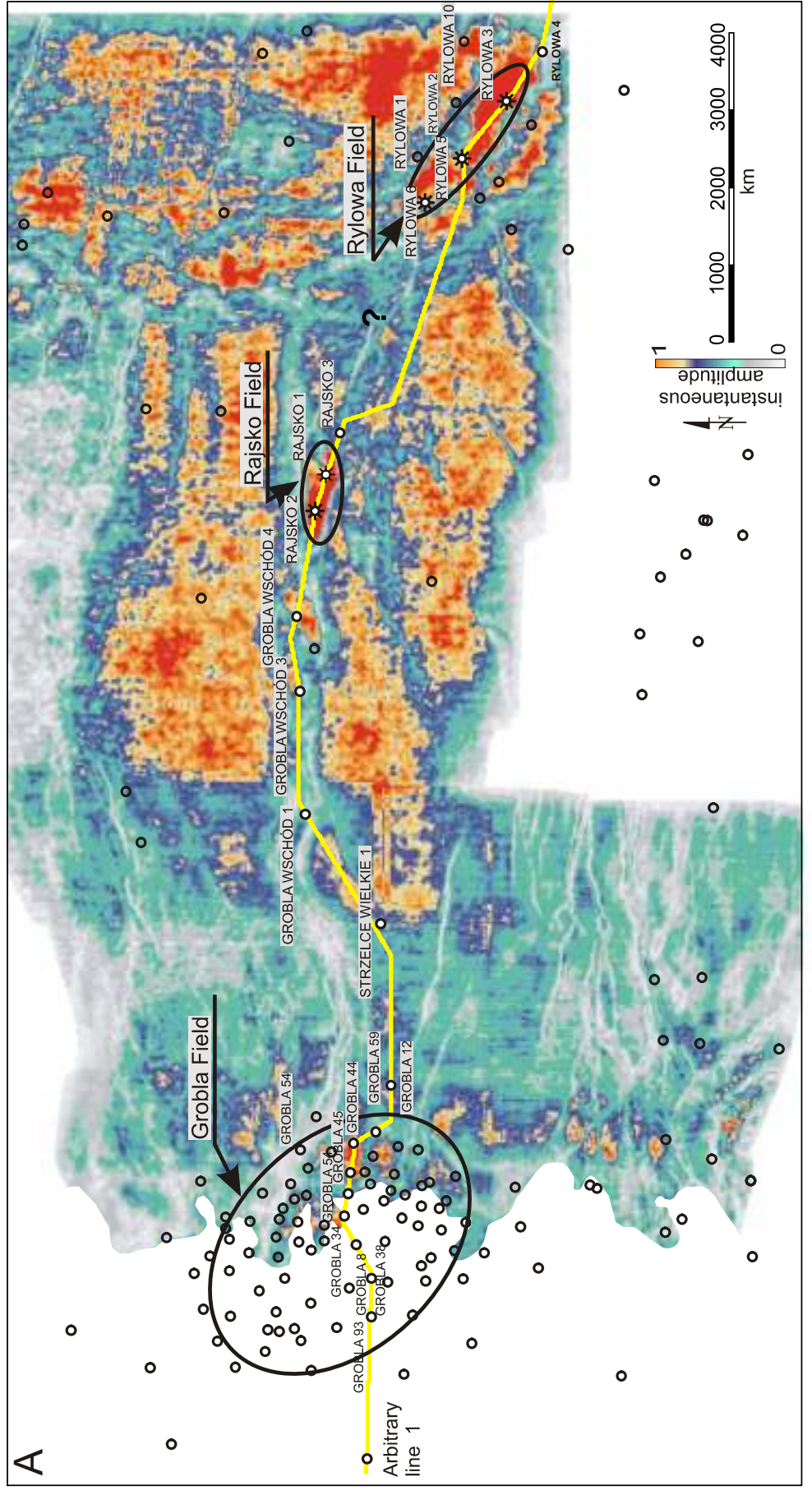

m

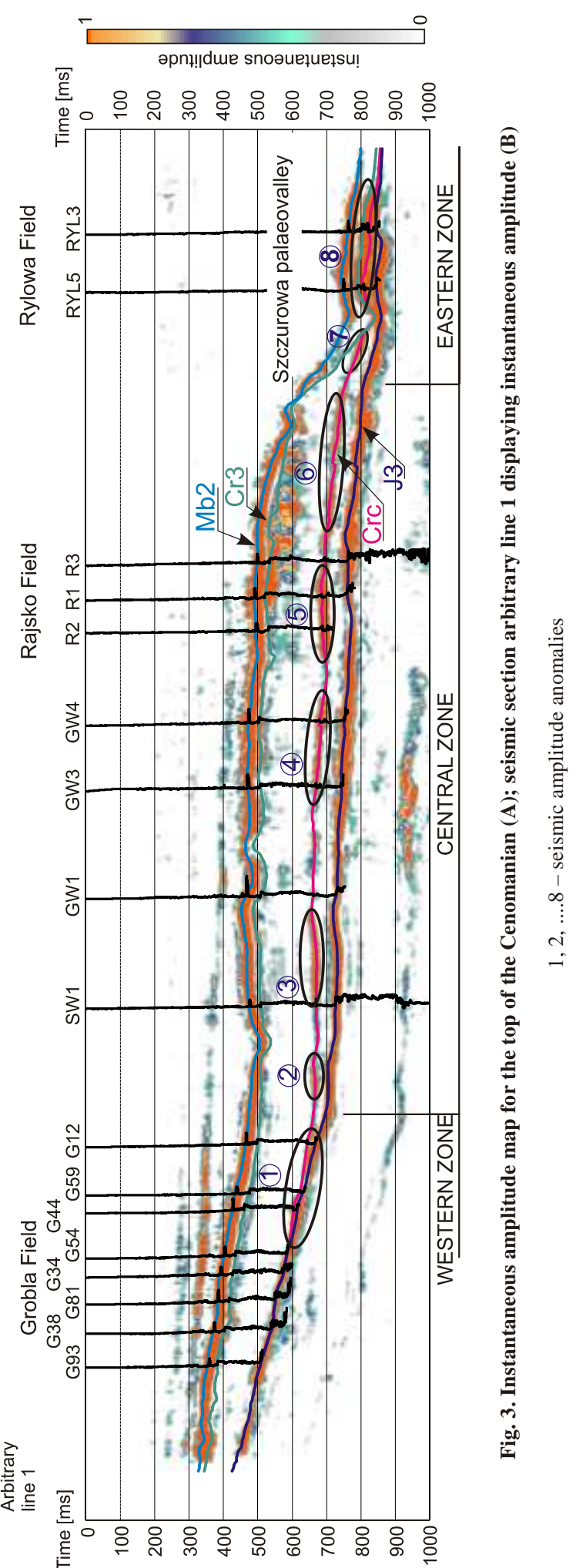

base of the Cenomanian, there are no other seismic reflectors which could significantly influence the amplitude of the composite signal and its envelope (instantaneous amplitude). Therefore, the data can be analysed using plots of amplitude calibration and stratum thickness (Kallweit and Wood, 1982; Brown et al., 1986). The plots correlate data recorded in the field with model based on analytically calculated tuning curves. Figure 5 sshows a calibration plot of composite amplitude (absolute value summation of amplitudes) associated with the top of the Cenomanian succession and the top of the Jurassic strata. Real data were correlated with the tuning curve which was extracted from a synthetic section (Pietsch and Marzec, 2003) and with the tuning curve which was calculated based on an analytical solution (Marzec, 2009). The correlation shows that a high maxi- 
A

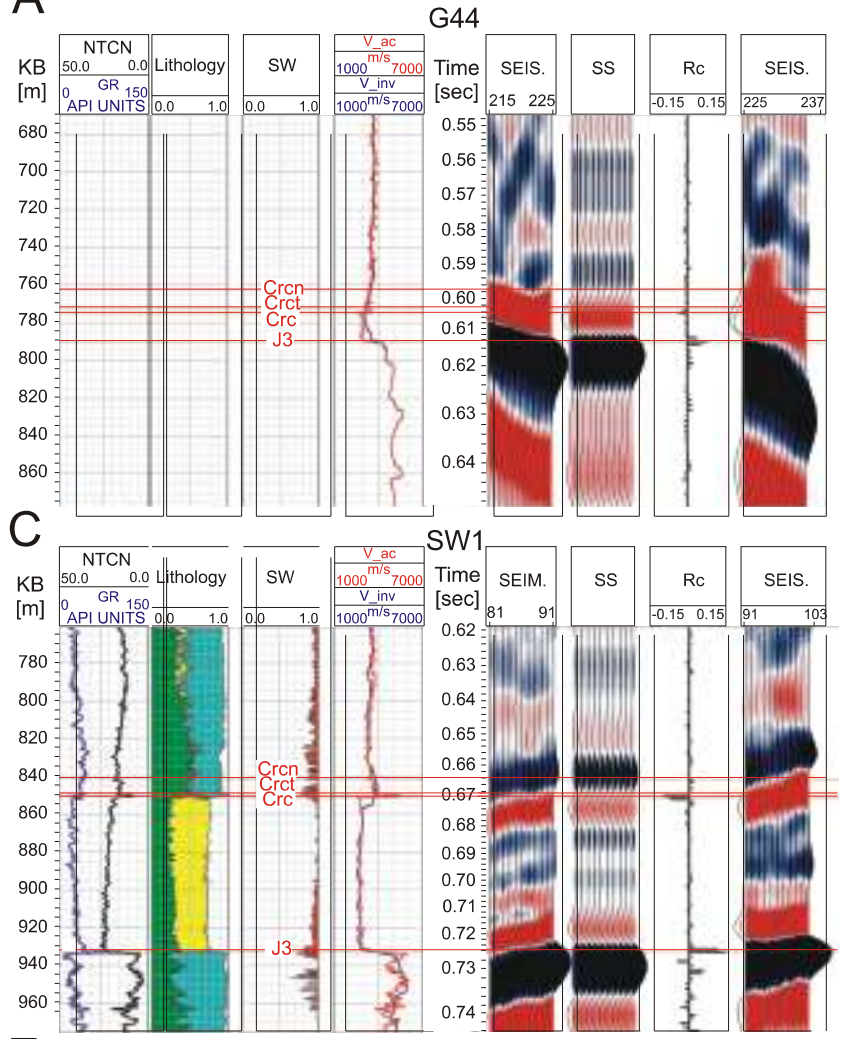

E

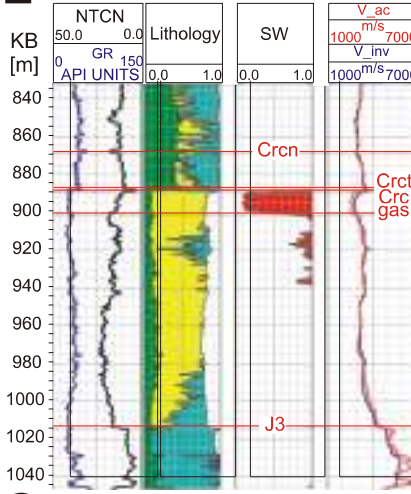

G

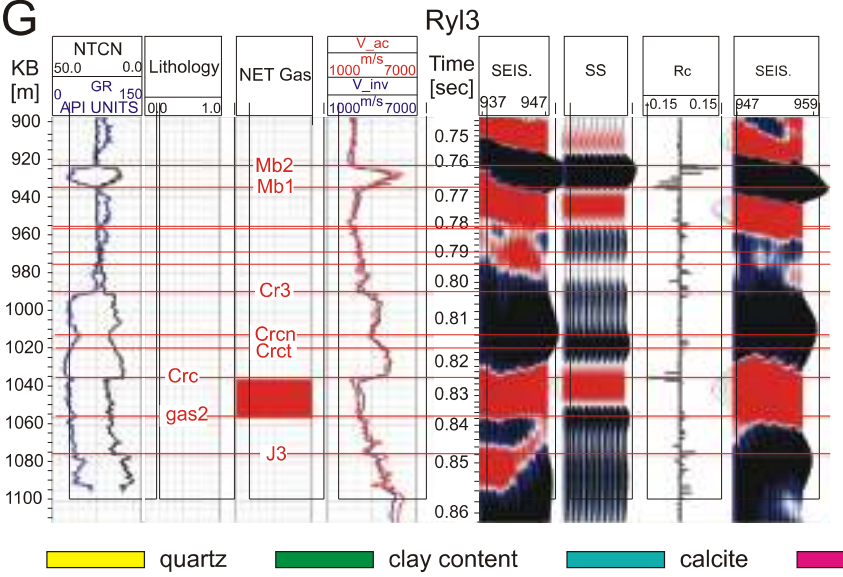

R1

\begin{tabular}{l|l|l|l|l}
\hline Time SEIM. & SS & Rc & SEIS. \\
\hline
\end{tabular}
B

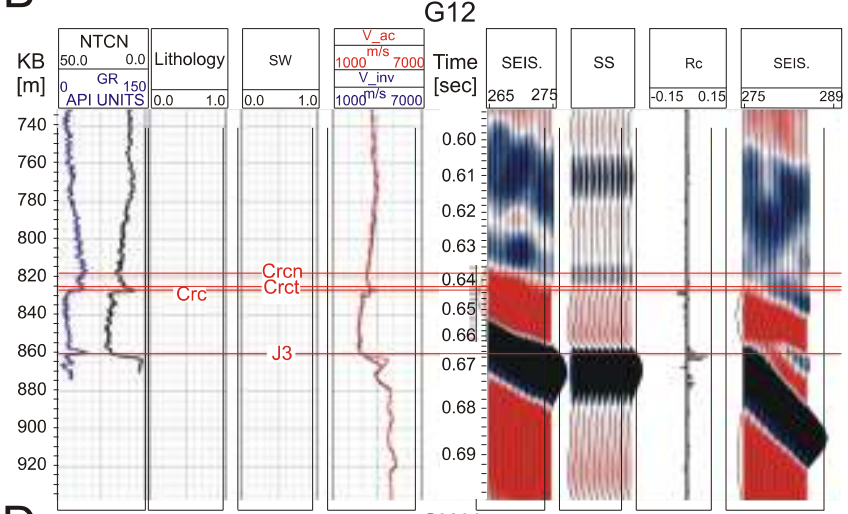

GW4

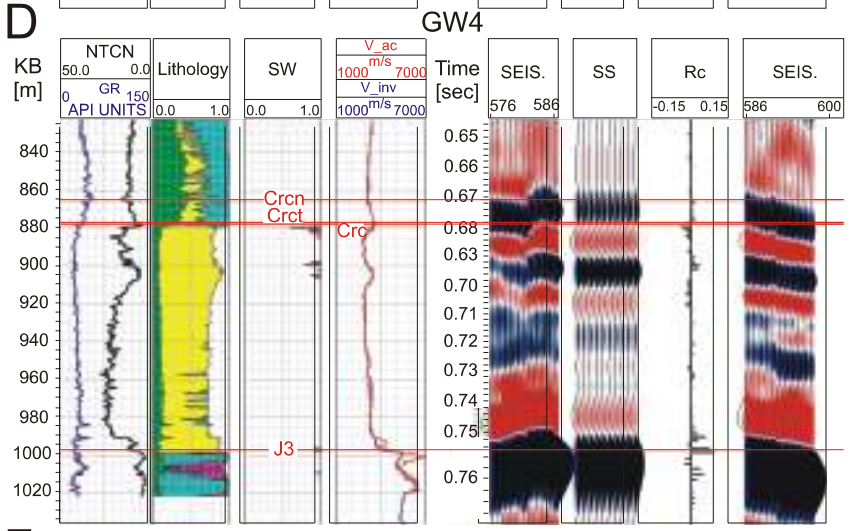

$\mathrm{F}$ Ryl5

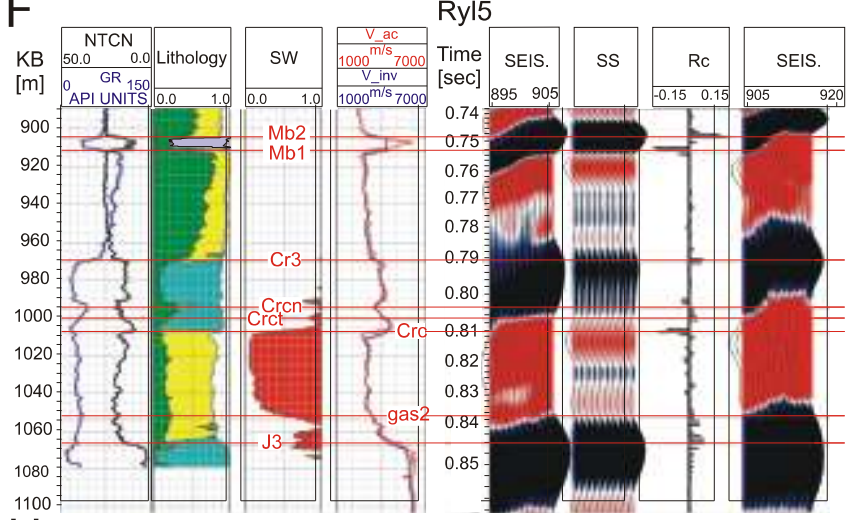

$\mathrm{H}$

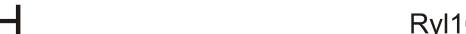

Fig. 4. Correlation of borehole-log data with surface seismic data from the western $(A, B)$, central $(C-E)$ and eastern zones $(\mathrm{F}-\mathrm{H})$ of the study area

NTCN - neutron porosity, GR - gamma-ray log, SW - water saturation, V_ac. - velocity from sonic logging (measured in borehole and calibrated with mean velocities), V_inv. - velocity derived from seismic inversion based on the geological model, SEIS. - seismic traces, SS - synthetic seismogram generated based on source data extracted from the seismic data, Rc - distribution of reflection coefficient calculated with time-steps of 1 ms 
mum amplitude (tuning effect) is present when the thickness of the Cenomanian stratum is $14 \mathrm{~m}$. The zone of high amplitude is apparent when the stratum thickness is up to about $20 \mathrm{~m}$. Within the zone, where isopachs have higher values, the weak amplitude is strengthened due to tuning of the side-lobes of wavelets (stratum thickness of 30 and $48 \mathrm{~m}$ ). It can be assumed that above a thickness of $55 \mathrm{~m}$ there is no detectable interference between reflections from the top and base of the Cenomanian stratum. The majority of the recorded amplitudes are located below the calculated tuning curve. Thus, the presence of gas in the Cenomanian succession can be ruled out, as the presence of gas, which lowers acoustic impedance, would result in reflection coefficient values giving amplitudes significantly stronger than those shown on the calculated tuning curves.

This is confirmed by borehole data as no gas was recorded in the Grobla 12 borehole, while the Grobla 44, 45 and 54 boreholes were drilled in the zone of oil saturation which does not cause such a significant decrease in acoustic impedance as does natural gas. The $55 \mathrm{~m}$ isopach defines the boundary between the western and central zones of the study area (Fig. 1C).

\section{CENTRAL ZONE}

The central zone covers the area where the influence of the reflection coefficients associated with the base of the Cenomaniam succession on the amplitude of reflections from the top of the Cenomanian is negligibly small. The amplitude of such reflections depends on the impedance contrast along the interface between the Turonian and the Cenomanian strata and on the presence of thin beds (in relation to seismic wavelength) as- sociated with surfaces of acoustic impedance contrasts. Seismic events generated along such bedding surfaces interfere with events associated with the Turonian/Cenomanian boundary, altering in various ways their amplitudes and shapes.

The Strzelce Wielkie 1 borehole is located between the anomalous areas marked by numbers 2 and 3 on Figure 3B. No high values of instantaneous amplitude were recorded near this borehole (Fig. 3A). Basically, constant values of compressional wave velocity were recorded within the Cenomanian strata in this borehole (Fig. 4C; curves V_ac and V_inv). A high negative value of reflection coefficient is observed only at the top of the succession, while a positive value is observed at its base. This shows that the Cenomanian sandstone drilled by this borehole is homogeneous in terms of velocity, which is supported by the uniform values of porosity and clay content (Fig. 4C; lithology track). The sandstone is overlain by a thin bed $(2 \mathrm{~m}$ thick) of Turonian limestone. Despite the high velocities these limestones do not have any significant influence on the amplitude and shape of the reflected signal from the top of the Cenomanian. The only detectable increase in seismic amplitude due to interference is caused by a slight increase in the velocity gradient within the approximately $20 \mathrm{~m}$ thick bottom part of the Senonian succession. This may be due to the decrease in clay content within the Coniacian marlstone (Fig. 4C). Due to the fact that the Cenomanian sandstone is not saturated with gas and there is no clear interference in this zone, the amplitude of the Cenomanian event (Crc on Figs. 2, 3B and 4C) is weak in this part of the seismic image. The Strzelce Wielkie 1 borehole can be used as a reference for further analysis of borehole logs and seismic data from the central zone of the study area.

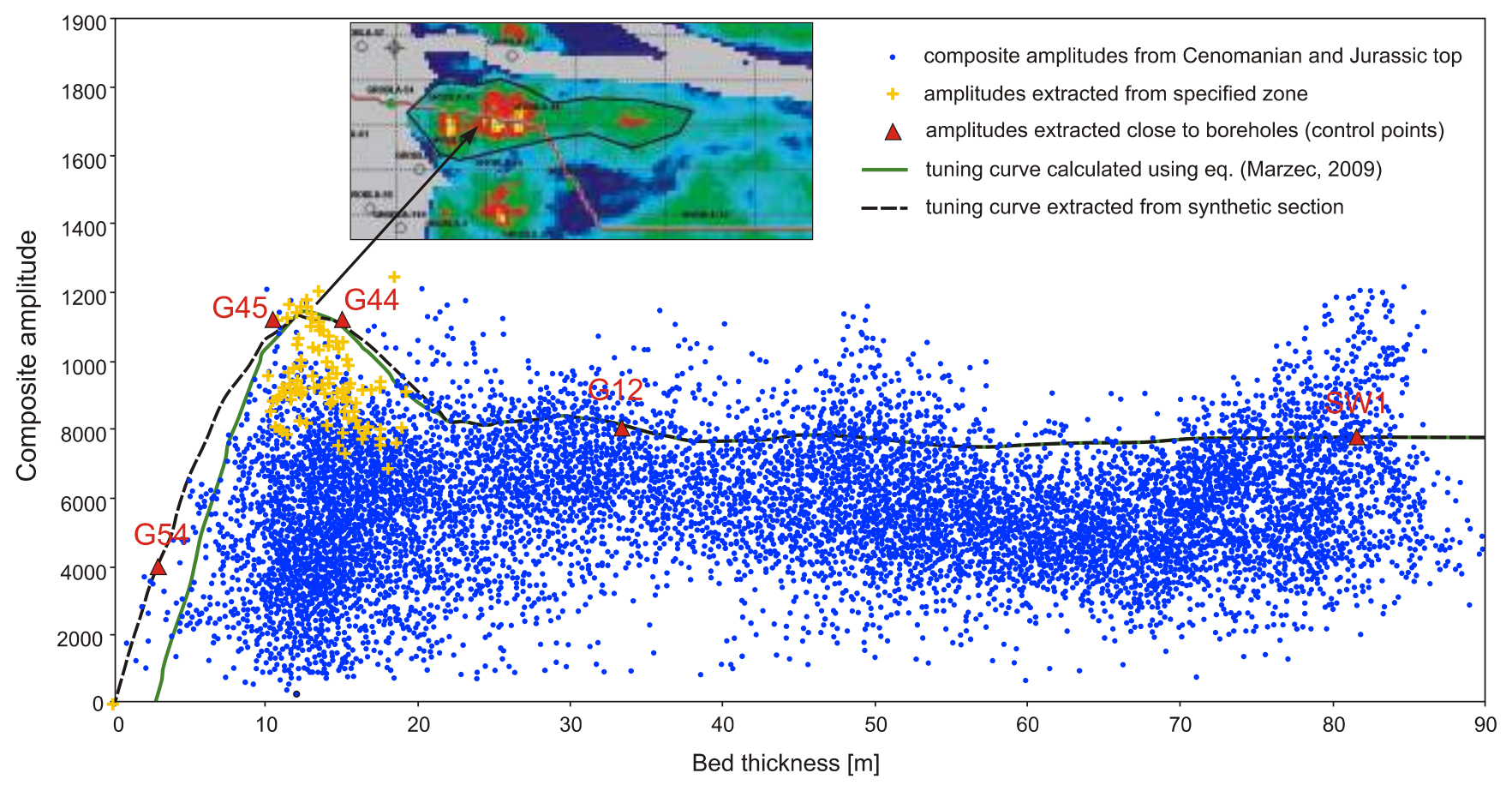

Fig. 5. Correlation of the composite amplitude curve with stratum thickness and tuning curve calculated and estimated based on the synthetic section (after Marzec, 2009) 
As in the case of the Grobla Wschód 3 and Grobla Wschód 4 boreholes (GW4; Fig. 4D) is also located within an anomalous area, and this area is marked number 4 (Fig. 3B). No significant hydrocarbon accumulation was encountered in either of these boreholes. A high-velocity bed, which is $10 \mathrm{~m}$ thick (similar to the tuning thickness) and has reduced porosity, was recorded in this borehole $20 \mathrm{~m}$ below the top of the Cenomanian (Fig. 4C). The reflection coefficients associated with the top and base of this bed generate reflections which positively interfere with reflections from the top of the Cenomanian, increasing their amplitude and modifying the shapes of wavelets. In this borehole, the thickness of the Turonian decreases to $1 \mathrm{~m}$. Thus, the obvious cause of anomalous records (false bright spot) is the presence of the reduced-porosity sandstone within the top part of the Cenomanian (Fig. 4D; SS and SEIS. track). In addition to that, this bed generates reflections that resemble a flat spot (horizontal and always positive reflex on the contact between zones saturated by gas and water), another reservoir indicator of possible hydrocarbon accumulation. In parts of the seismic section (Figs. 2 and 4D) it is apparent, however, that this reflection event is not horizontal, but reflects the shape of the Cenomanian top, with displacement on the fault.

Both, the Rajsko 1 borehole (R1; Fig. 4E) and the Rajsko 2 borehole are located within the anomalous area marked number 5 (Fig. 3B). In both these boreholes, feasible gas accumulations were encountered in the upper part of the Cenomanian succession (Fig. 4E; SW track and velocity drop - track: V_ac V_inv). Below, as in the Grobla Wschód 4 borehole, much thicker (37 m thick) strata of higher velocity and lower porosity occur due to the presence of calcite cement in the sandstone layer (Fig. 4E; lithology track). The presence of gas results in a significantly higher negative value of reflection coefficient associated with the top of the Cenomanian. The presence of gas also produces a positive reflection coefficient associated with the gas/water interface which increases the impedance contrast along the top of the reduced-porosity bed (Fig. 4E; SW track, Rc track, NTCN track). Thus, there is an increase in seismic amplitude greater than in the case of the Grobla Wschód 4 borehole (Fig. 4D) and there is a real flat spot (Fig. 2) which here is flat-lying (Fig. 4E; SS track and SEIS. track). The high-velocity stratum at the base of the Senonian has a thickness which is slightly larger than the tuning thickness. Thus, positive reflection coefficients along the top of this bed further increase the amplitude of reflection events associated with the top of the Cenomanian. Here, there are two strata (in the Grobla Wschód 4 borehole; Fig. 4D) there is a system of three beds, while in the Strzelce Wielkie 1 borehole (Fig. 4C) there is one bed, the mutual thickness relationships of which alter the amplitude and shape of the reflections originating from the decrease in acoustic impedance along the top of the Cenomanian succession.

\section{EASTERN ZONE}

In this area, the Cenomanian sandstones not only form a thinning wedge, but there is also an erosional incision associated with the Szczurowa palaeovalley that is filled with Miocene siliciclastics of the Carpathian Foredeep. Thus, the inter- ference at the top of the Cenomanian is additionally affected by the influence of the reflected signal from the base of the Miocene succession (Fig. 2).

The Rylowa 5 borehole (Ryl5; Fig. 4F) is located within the anomalous area marked number 8 (Fig. 3B). Almost the entire Cenomanian reservoir is saturated with gas $(45 \mathrm{~m})$, therefore there is no flat spot, i.e. reflection events related to the contact between gas and water. The presence of gas increases the reflection coefficient values at the top and base of the Cenomanian, and results in the presence in seismic data of the classic bright spot (Fig. 4F; SS track i SEIS. track).

Above the Cenomanian, the high-velocity Turonian $(4500 \mathrm{~m} / \mathrm{s})$ and Senonian $(4000 \mathrm{~m} / \mathrm{s})$ beds are covered by low velocity Miocene deposits (Fig. 4F; lithology track, V_ac and $\mathrm{V}$ _inv, Rc). Along the top boundaries of the Turonian and the Senonian successions, a strong positive double reflection is visible. The superposition of the positive events from the Turonian and the Senonian strata and of the negative one from the top of the Cenomanian results in an additional increase in the seismic amplitude and in modification of the shape of the composite signal (Fig. 4F).

In the Rylowa 3 borehole (Ryl3; Fig. 4G) the structural and stratigraphic situation is similar to that in the Rylowa 5 borehole. However, the thickness of the Turonian limestone in the Rylowa 3 borehole is significantly larger, which makes the event from the base of the saturated zone visible (flat spot; Fig. 4G). The thickness of the Cenomanian sandstones is much smaller (41 m), while the base of the saturated zone generates a clear flat spot which is apparent both on the synthetic section (Fig. 4G) and in the seismic data from the area to the west of the borehole (Figs. 2 and 3). The thickness of the saturated zone in this borehole is similar to the tuning thickness (20 m).

The Rylowa 10 borehole is located outside the Rylowa field (Fig. 3A). No gas was recorded in this borehole, although anomalously high values of reflected signal from the top Cenomanian reflector are observed. This is due to the fact that the Cenomanian sandstone wedges towards the east. Thus, here, the reflected signals from the top of the Cenomanian stratum and the top of the Jurassic interfere (tuning zone) in a similar way as in borehole Grobla 44 (G44; Fig. 4A).

The analysis of seismic amplitude anomalies from borehole data indicates on two main reasons for their occurrences:

- the presence of gas accumulations in the Cenomanian strata,

- positive interference of the event from the top of Cenomanian and the events from boundaries that form thinbedded configurations with the top of the Cenomanian.

The positioning of boreholes in the research area, particularly the ones executed in recent years, has been based on amplitude anomalies (Fig. 3). A number of these showed that the selected location was wrong (among others Fig. 4A-D, H).

It has become apparent that the reservoir seismic interpretation, based on analysis of anomalously enhanced amplitude, needs to be preceded by identification of the zones where geometric enhancing of the amplitude is significant (zones of tuning). The question arises whether this type of identification can be achieved entirely on seismic data without borehole information? 


\section{THE CONCEPT OF THE INTERPRETATION PROCEDURE}

For traditional structural interpretation of seismic data the zero-phase seismic section is normally used (Figs. 2 and 6). An alternative approach involves rotating zero-phase seismic data by $270^{\circ}$ or $90^{\circ}$ and reversing its polarity (Zeng and Backus, $2005 \mathrm{a}, \mathrm{b}$ ) which is followed by determining the peak-to-trough amplitude and total amplitude based on such data. Peak-totrough amplitude $A_{m}(|A 1|+|A 2|$ in Fig. 6) is a function of signal envelope, while total amplitude ( $A 1+A 2$ in Fig. 6) is a measure of the shape of the signal and its shift in phase. If the reflected signal is free from interference, its value is zero. Positive and negative values indicate interference due to the presence of additional seismic reflectors below or above the interface analysed. Lateral changes in the value of this parameter along the seismic interface may indicate changes in stratal thicknesses.

Figure 7 shows a synthetic section rotated by $270^{\circ}$ and calculated using a Ricker-type signal for a schematic model of a thinning wedge. The most significant features of the model are:

- reverse reflection coefficient on the top and base of the strata;

- "wedge" shape of the strata, that allows simulation of the seismic image from a thin layer (interfered signal) as well as from a thick one.

The values of peak-to-trough amplitude $A_{m}$ and total amplitude of reversed polarity $f_{1}$, which were calculated for the reflections from the top of the stratum, were summarized with the amplitude $A_{d}$ (Fig. 8A) which is based only on the value of the reflection coefficient Rc. The attribute defined in such a way may serve as an indicator of the interference effect related to a

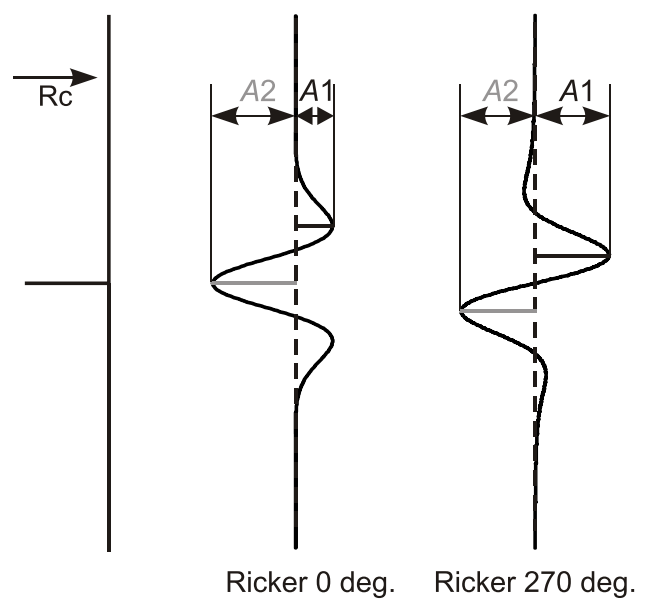

Fig. 6. Principle of calculating peak-to-trough amplitude $\left(A_{m}\right)$ as well as total amplitude based on seismic data rotated by $270^{\circ}$

Rc - reflection coefficient, $A 1$ - peak amplitude $(+), A 2$ - trough amplitude (-), $A 1+A 2$ - total amplitude, $|A 1|$ $+|A 2|-$ peak-to-trough amplitude (total absolute amplitude)

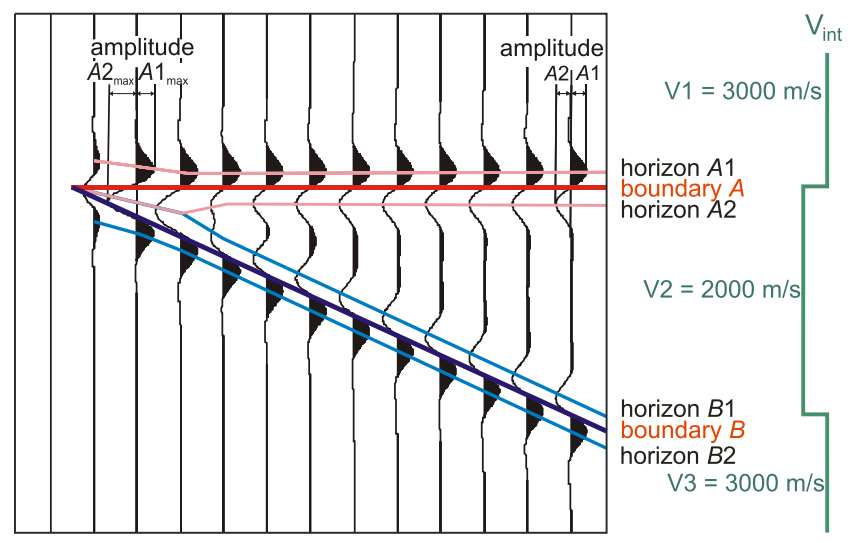

Fig. 7. Principle of seismic horizon picking based on synthetic data rotated by $270^{\circ}$ which was generated based on the schematic model of the thinning stratum

lateral thinning of beds studied. Therefore the attribute can be applied to determine the transfer function which is used for removing the effects of the increase in amplitude due to interference.

If we assume, after Brown et al. (1986), that the effect of the geometric amplification may be added to amplitudes which result from the reflection coefficient, the transfer function for the amplitude horizon map $A_{m}$ can be defined as:

$$
A_{m}(\mathrm{x}, \mathrm{y})=A_{d}(\mathrm{x}, \mathrm{y})+F(\mathrm{x}, \mathrm{y})
$$

where: $A_{m}$ - peak-to-trough amplitude of the reflections from a seismic interface; $F$ - transfer function; $A_{d}$ - peak-to-trough amplitude of reflections which is based only on a reflection coefficient (expected amplitude); $x, y-$ coordinates or inline/cross-line.

Based on the modelling results (Fig. 7), approximation of the transfer function $\mathrm{F}$ can be defined in the following way:

$$
f_{3}=f_{1} \cdot a \cdot b=(-1)(A 1+A 2) \cdot a \cdot b
$$

where: $f_{1}$ - total amplitude of reversed polarity; $a$ - scaling coefficient based on modelling data depends on reflection coefficient ratio from the top and the base of the strata, as well as on the shape of the source signal; $b$ - control coefficient based on time thickness limiting the function to the tuning zone.

$$
a \cong \frac{F \max }{f_{1} \max }=\frac{A_{m} \max -A_{d}}{(-1)(A 1 \max +A 2 \max )}
$$

$$
b=\left(\frac{A 1-A 2_{-} \text {isochron }}{A-B_{-} \text {isochron }}\right)^{n}
$$

where: $A 1-A 2 \_$isochron - time thickness between horizon $A 1$ and horizon $A 2$ (Fig. 7); $A-B$ _isochron - time thickness between zero-crossing picked boundary $A$ and $B$ (Fig. 7); $n$ - taper factor. 
A
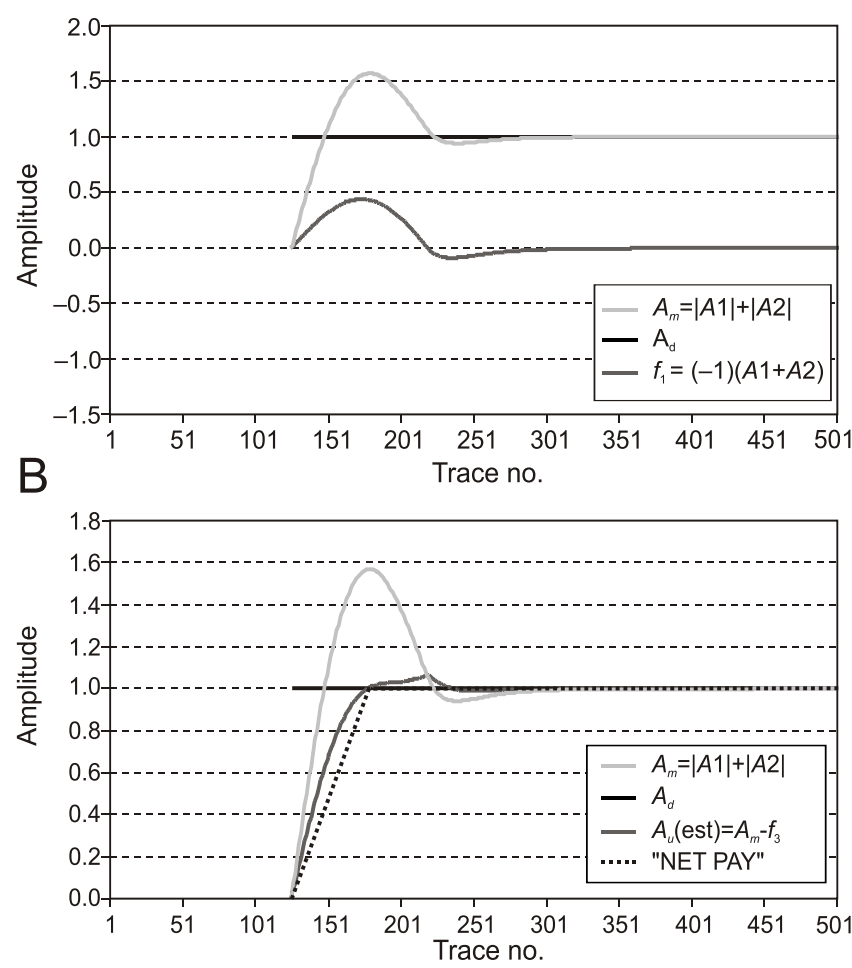

Fig. 8. Schematic drawing showing the principle of removing the tuning effect based on model data

A - comparing the transfer function $f_{1}$ and peak-to-trough amplitude $A_{m}$ determined for the reflections along the top of the wedging stratum (Fig. 6) with the amplitude $A_{d}$ based on reflection coefficient values; $\mathbf{B}$ - comparing peak-to-trough amplitude before $\left[A_{m}\right]$ and after $\left[A_{u}(\mathrm{est})\right]$ application of the transfer function $f_{3}$ with a plot of the net pay parameter

For constant values of reflection coefficients associated with the top and the base of the stratum and for the signal resembling the Ricker-type wavelet, the value of scaling coefficient a is 1.33 in the zone of high maximum amplitude due to the tuning effect, and it is independent of the seismic velocity associated with a wedging bed (Marzec, 2004).

Application of the above procedure and a smoothing filter results in the $A_{u}$ (est) attribute which represents peak-to-trough amplitude without the tuning effect in the zone of the wedging bed (Fig. 8B). The attribute does not reconstruct the amplitude value related to the reflection coefficient below the resolution limit; however, it is a good approximation of the seismic net pay (Connolly, 2007).

\section{CRITERIA OF CLASSIFICATION AND INTERPRETATION OF AMPLITUDE ANOMALIES BASED ON THE RESULTS OF 2-D MODELLING}

In order to determine the origin of the amplitude anomalies observed on real seismic data, the interpretation flow developed was tested developed using theoretical models approxi- mating subsurface geology. Seismic-geological models were based on the arbitrary profile 1 , for which phase correction was made by applying a shaping filter operator which was determined by correlating seismic traces with the distribution of reflection coefficient values from borehole-log data (Marzec, 2009).

Seismic-geological models were prepared using borehole velocity data (Fig. 4), results of seismic inversion (Pietsch et al., 2005) and the geometry of seismic reflectors seen on seismic arbitrary line 1 extracted from 3-D volume (Fig. 3). Synthetic seismic data was generated using the Struct application from GeoGraphix (Landmark Halliburton) software by applying a vertical incidence algorithm which simulates post-stack, migrated seismic data. The signal extracted from recorded seismic data was used to generate synthetic data. A $270^{\circ}$ phase rotation of the synthetic data was made and applied which was followed by picking the positive (C1) and negative (C2) phases of reflections from the top of the Cenomanian. Synthetic data showing instantaneous amplitude were also generated. The synthetic sections were used to determine the peak-to-trough amplitude $(\mathrm{Cm})$ of the seismic event generated at the top of the Cenomanian $(\mathrm{Crc})$ and various options of the transfer function for this event.

\section{WESTERN ZONE}

The model (Fig. 9A) covers an area where the Cenomanian forms a thinning wedge (anomalies no. 1 and 2 in Fig. 3B). Its thickness is the greatest in the Strzelce Wielkie 1 borehole, while in the Grobla 12 borehole it reaches about $30 \mathrm{~m}$, and in the area of the Grobla 38 borehole the Cenomanian is approximately $1 \mathrm{~m}$ thick. Thus, the profile shows the transition from the thick bed to the thin bed already below the resolution of seismic data. The constant seismic velocity used for the Cenomanian was equal to the lowest velocity measured for the Cenomanian rocks in boreholes located in this area. The synthetic seismic profile (Fig. 9B) shows a clear increase in the amplitude due to thinning of the Cenomanian stratum where reflections from the top and base of the bed start to interfere (tuning zone, CDP 200-470). The peak-to-trough amplitude plot for the top of the Cenomanian ( $\mathrm{Cm}$ in Fig. 9C) shows that the highest amplitude values of reflection from the Cenomanian top $\mathrm{Crc}$ are associated with a bed thickness ranging between 10 and $25 \mathrm{~m}$ (between CDP 200 and 500). The transfer function $f_{3}$, calculated using the synthetic data, has positive values [parameter $\mathrm{a}=1.34$ (formula 3 ) and $\mathrm{n}=3$ (formula 4)]. This indicates the dominant influence of reflections from the top and base of the Cenomanian on the shape and amplitude of the composite seismic response.

The result is analogous to the case where there is one wedging stratum (Fig. 8A, B). The peak-to-trough amplitude in the tuning zone is reduced to the level characteristic for the largethickness stratum. Due to the large difference between reflection coefficients at the top and the base of the thinning bed (Fig. 4A), high negative amplitude values $\mathrm{Cd}\left(f_{3}\right.$; Fig. 9C) are associated with a bed thickness smaller than $3-4 \mathrm{~m}$. This is due to a decrease in the influence of interference between reflec- 
A

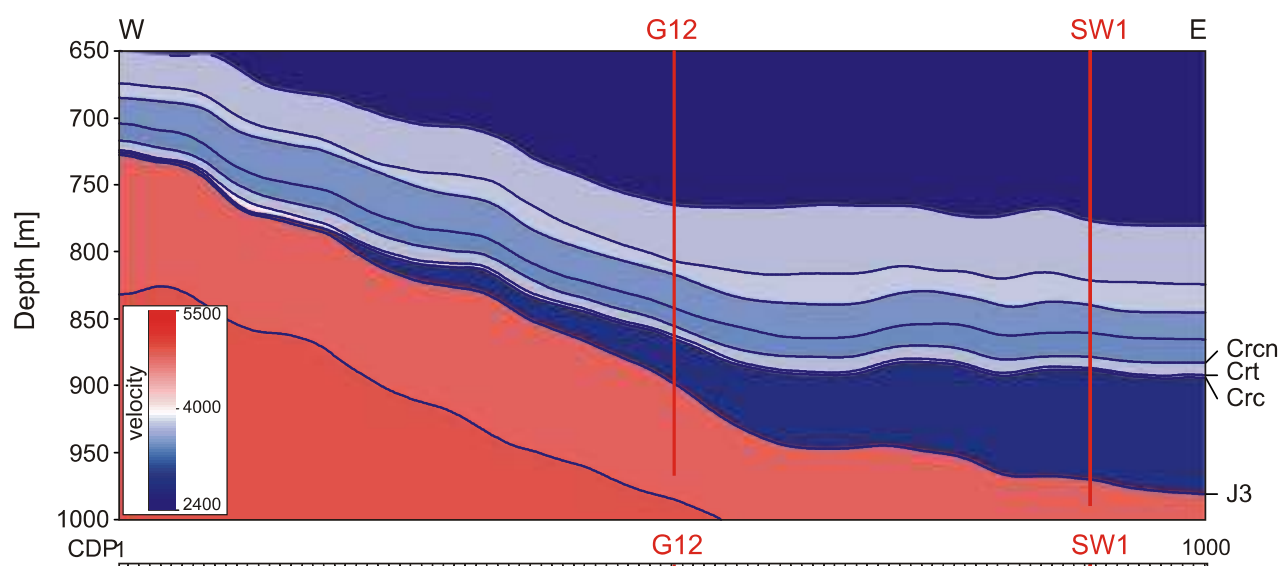

B

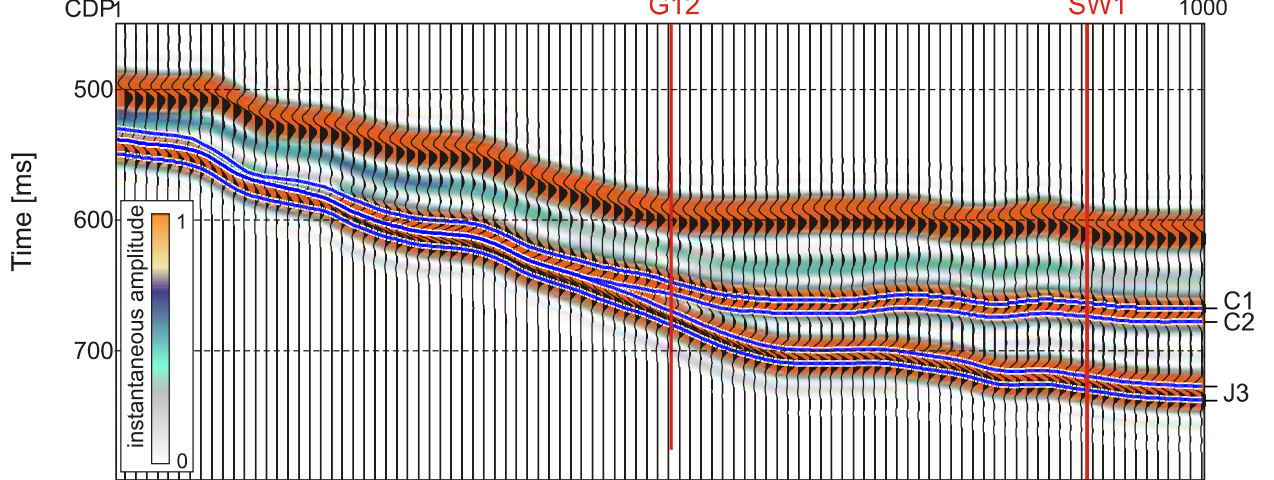

C

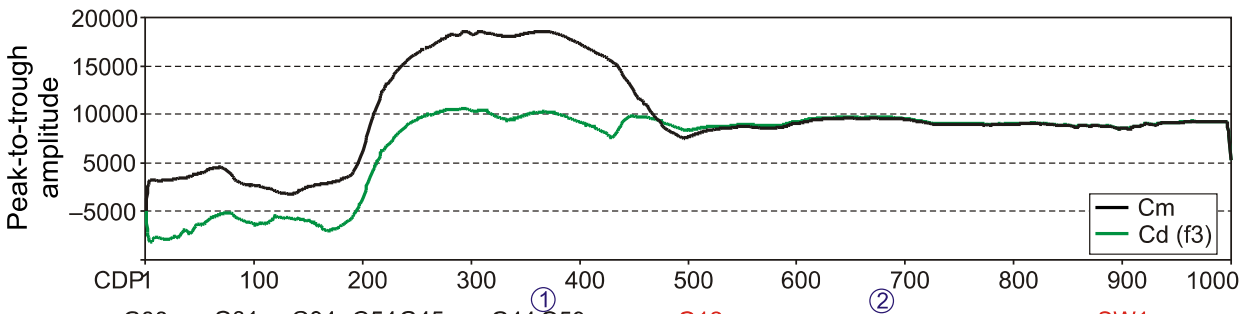

D

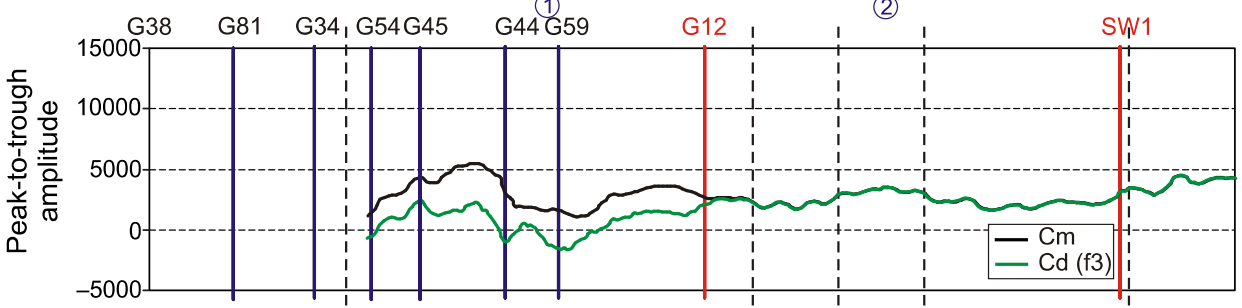

E G81 G34 G54 G45 G44 G59 G12 sW1

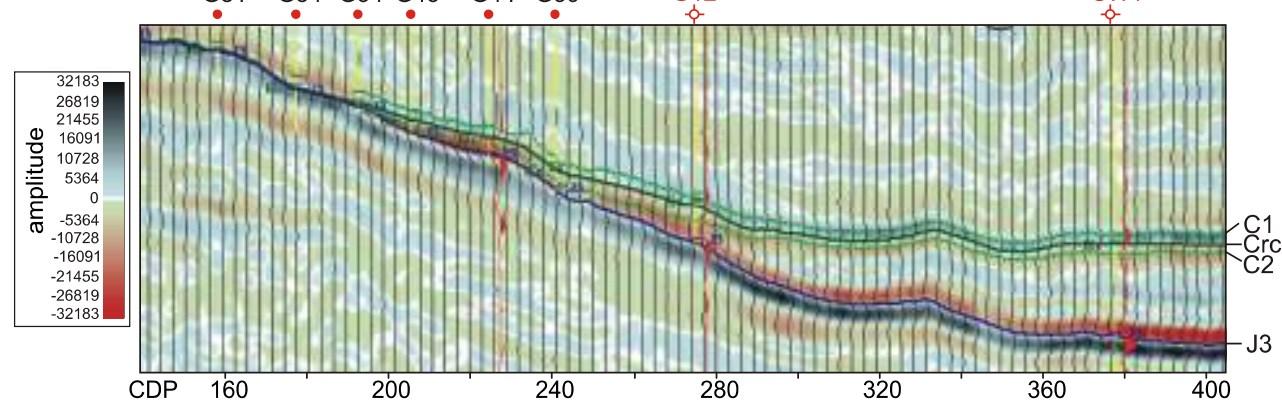

Fig. 9. Criteria for interpretation of the amplitude map for the top of the Cenomanian boundary in the area of the thinning wedge based on model data (western part of the Grobla-Rajsko-Rylowa area)

A - seismic-geological model; B - synthetic data rotated by $270^{\circ}$ (wiggle traces) and data displaying instantaneous amplitude (colour); $\mathbf{C}$ - peak-to-trough amplitude plot before $(\mathrm{Cm})$ and after applying the transfer function $\mathrm{Cd}\left(f_{3}\right)$ for the top Cenomanian reflector $(\mathrm{Crc})$ based on synthetic data; $\mathbf{D}$ - peak-to-trough amplitude plot before $(\mathrm{Cm})$ and after applying the transfer function $\mathrm{Cd}\left(f_{3}\right)$ for the top Cenomanian reflector $(\mathrm{Crc})$ based on real data; $\mathbf{E}$ - part of seismic section arbitrary line 1 which corresponds to the seismic-geological model (Fig. $8 \mathrm{~A}$ ) after phase rotation by $270^{\circ}$ 
tions, associated with the opposite-sign reflection coefficients, on the composite seismic signal. Simultaneously, there is an increase in the influence of interference between reflections associated with reflection coefficients of the same polarization (strata overlying the Cenomanian). This thickness can be considered as critical for detecting the Cenomanian strata on the seismic data in the western zone. In the case of the real seismic data (Fig. 9D, E), reduction of the maximum amplitude values $\mathrm{Cd}\left(f_{3}\right)$ (anomalous area no. 1 between boreholes G54 and G12) to the same or lower levels as those associated with the "thick" bed is also observed, as on synthetic data. The observed negative amplitude values indicate that the Cenomanian thickness is below the detection limit (in the vicinity of borehole G54, Cenomanian thickness $-3 \mathrm{~m}$ ). The amplitude values observed may also be a result of a decrease in reflection coefficient along the top the Cenomanian (between boreholes G44 and G59). The decrease in reflection coefficient is a result of increasing acoustic impedance of the Cenomanian deposits (reduction in porosity or change in sedimentary facies). Nevertheless, in this zone the significant amplitude decrease $\operatorname{Cd}\left(f_{3}\right)$ should be linked to the reduced total thickness of the porous sandstone associated with low acoustic impedance (reduced net pay). Outside the tuning zone, i.e. to the east of borehole G12, application of function $f_{3}$ did not change the values of peak-to-trough amplitude. Its non-zero, positive values are good indicators of the tuning zone associated with wedging of the Cenomanian sandstones.

\section{CENTRAL ZONE}

The model of the anomalous area, located between the Strzelce Wielkie 1 and Grobla Wschód 1 boreholes (Fig. 3B, anomaly no. 3), from which no borehole data was available, was constrained by assumption of the stratified nature of the Cenomanian and its overburden. The seismic anomaly on the time section (Fig. 10E) was assumed to be a result of data distortion produced by an increase in thickness of the high-velocity bed present above the Cenomanian. Its thickness increases to the critical value of about $9 \mathrm{~m}$ in accordance with the Widess criterion (1973). This can be simulated by increasing the velocity gradient in the bottom part of the Senonian succession (Fig. $4 \mathrm{C}-\mathrm{E}$ ) and increasing the thickness of the Turonian (Fig. $4 \mathrm{~F}-\mathrm{H}$ ). The synthetic section (Fig. 10B) shows an increase in the amplitude without altering the wavelet shape. The increase in the instantaneous amplitude resembles a bright spot. Negative values of the transfer function $\left(f_{2}=f_{1} \cdot\right.$ a) clearly indicate that the high-amplitude anomaly is a result of interference between the reflections associated with the top of the Cenomanian and the top of its high-velocity overburden. As a result of applying the transfer function, there is an increase, instead of a decrease, in the peak-to-trough amplitude $\left[\operatorname{Cd}\left(f_{2}\right)\right.$ in Fig. 10C]. The same result is observed on the real seismic data (Fig. 9D, E). Both the seismic records (Fig. 10E) and the values of peak-to-trough amplitude before and after applying the transfer function (Fig. 10D) support good correlation of the seismic record with the synthetic data as well as correct choice of the model. The high negative values of the transfer function indicate that the origin of the high amplitudes, observed along the top of the thick Cenomanian succession, is associated with the strata overlying it.

The model of the central part of the local Cenomanian Ba$\sin$ (anomalies no. 4 and 5 in Fig. 3B) is based on data from the Grobla Wschód 4 and Rajsko 2, 1 and 3 boreholes. It covers the area of the Rajsko field as well as the area located immediately to the west of the elevated zone near the Grobla Wschód 4 borehole (GW4) where no hydrocarbon saturation was assumed (Fig. 11A).

The model assumes the presence of a high-velocity bed above the top of the Cenomanian which is consistent with the borehole data (Fig. 4D, E). The synthetic data (Fig. 11B) indicate a clear increase in the amplitude in the reservoir zone. A smaller increase in the amplitude is also apparent in the area of borehole GW4. There are no noticeable differences in the shape of the signal between these two zones. The highest values of peak-to-trough amplitude $\mathrm{Cm}$ are associated with the reservoir zone (Fig. 11C). In this zone, the transfer function $f_{2}$ has positive values ranging from the maximum, where the gas-bearing zone has the largest thickness, to 0 where the gas-bearing zone has a thickness of $3 \mathrm{~m}$. In the area of borehole GW4, the function $f_{2}$ has negative values which are close to zero. In the area of borehole GW4, the peak-to-trough amplitude $\mathrm{C}$ virtually does not change when the function is applied. In the area of the Rajsko reservoir (Fig. 11C, CDP ca. 450 to ca. 900), after applying the transfer function, the peak-to-trough amplitude $\operatorname{Cd}\left(f_{2}\right)$ is reduced although the values observed are still higher than those in the area of borehole GW4 (Fig. 11D). In structural settings resembling the model presented here, the thickness of the gas-saturated zone of 4-5 $\mathrm{m}$ is the minimum thickness which allows unambiguous detection of the gas-bearing stratum. Seismic data show very similar records from the area of the Rajsko field and borehole GW4 (Fig. 11E). Analysis of the peak-to-trough amplitude plots (Fig. 11C) shows that the transfer function has positive high values within the area of the reservoir. As in the case of the anomalous area no. 3 (Fig. 10), the negative values of transfer function should be linked to the dominant influence of the geometry of the overlying strata.

\section{EASTERN ZONE}

In terms of its structure and stratigraphy, the model of the Rylowa gas field (Fig. 12A) is the most complex. Here, the Cenomanian forms a thinning wedge which in relation to the seismic signal can be classified as an initially "thick" bed gradually changing into a thin bed. The same applies to the saturated zone. The thickness of the Turonian, which overlies the saturated zone, also changes from $7 \mathrm{~m}$ in Rylowa 5 borehole to $15 \mathrm{~m}$ in Rylowa 3 borehole. The thicknesses of the overlying Cretaceous strata also change depending on the degree of their erosion. In the model, Miocene deposits filling the Szczurowa palaeovalley, deeply incised in its Cretaceous substratum, seal the reservoir from the west. The synthetic section shows high amplitude reflections (Fig. 12B) which are associated both with the reservoir and the western side of the palaeovalley. The plot of the peak-to-trough amplitude $\mathrm{Cm}$, associated with reflections from the top of the Cenomanian, makes the interpretation easier and more accurate. In this part of the reservoir, where the 


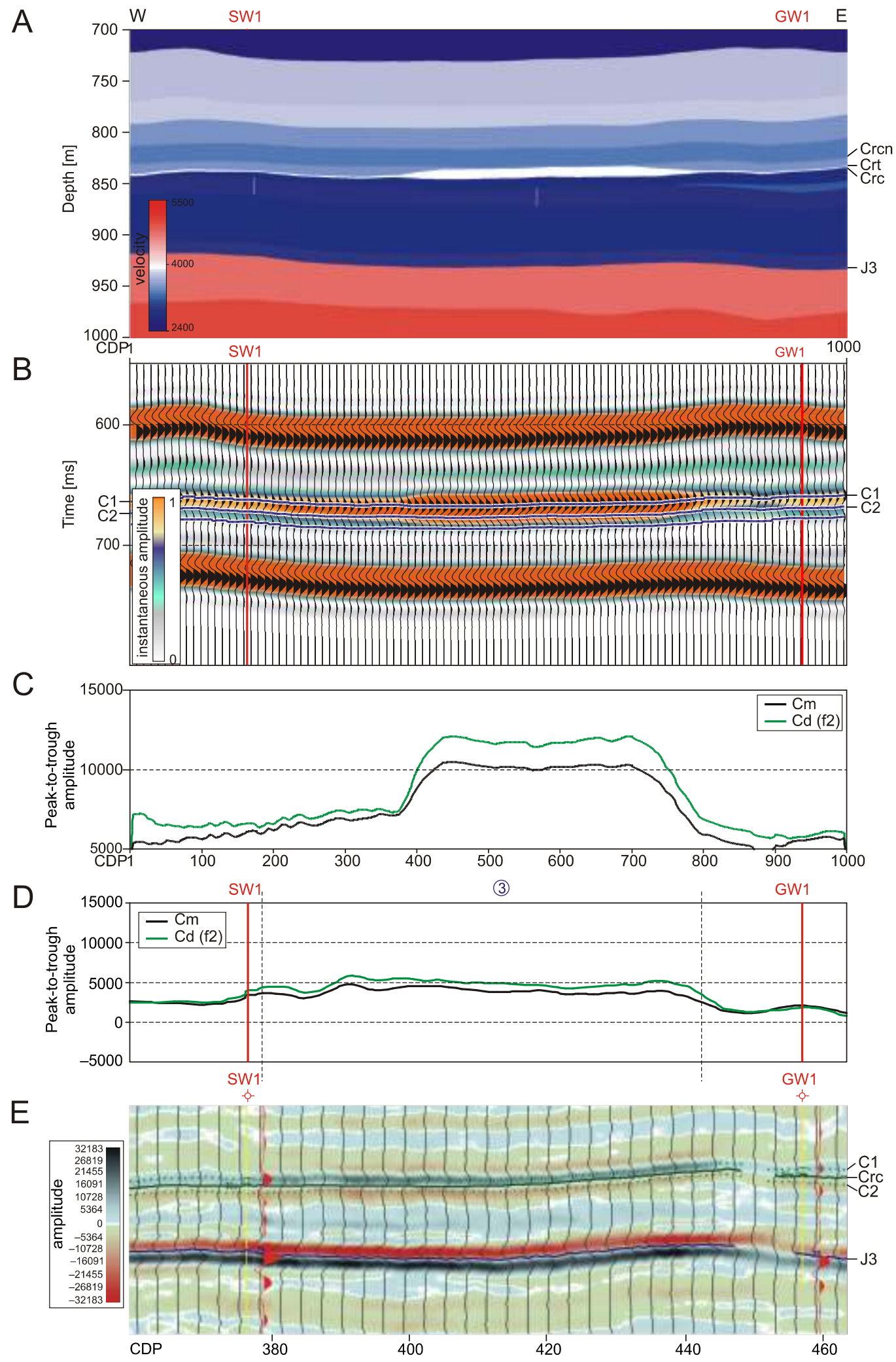

Fig. 10. Criteria for interpretation of the amplitude map for the top of the Cenomanian boundary in the area of increased thickness of the Turonian based on model data (central part of the Grobla-Rajsko-Rylowa area)

A - seismic-geological model; B - synthetic data rotated by $270^{\circ}$ (wiggle traces) and data displaying instantaneous amplitude (colour); $\mathbf{C}$ - peak-to-trough amplitude plot before $(\mathrm{Cm})$ and after applying the transfer function $\mathrm{Cd}\left(f_{2}\right)$ for the top Cenomanian reflector $(\mathrm{Crc})$ based on synthetic data; $\mathbf{D}$ - peak-to-trough amplitude plot before $(\mathrm{Cm})$ and after applying the transfer function $\mathrm{Cd}\left(f_{2}\right)$ for the top Cenomanian reflector $(\mathrm{Crc})$ based on real data; $\mathbf{E}$ - part of seismic section arbitrary line 1 which corresponds to the seismic-geological model (Fig. 9A) after phase rotation by $270^{\circ}$ 
A

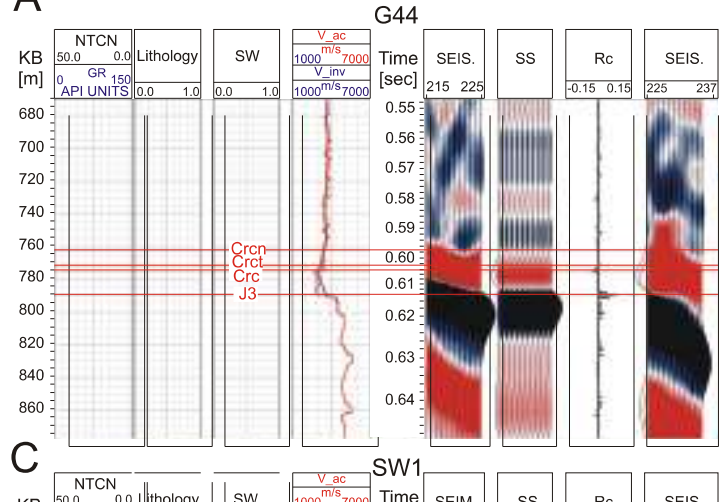

B

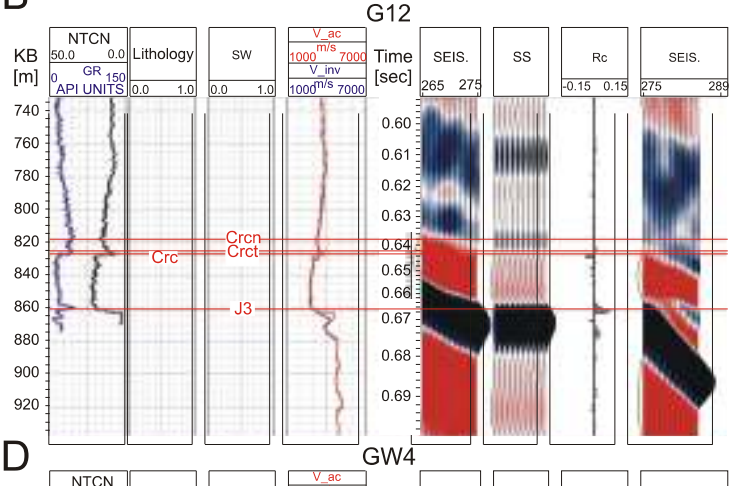

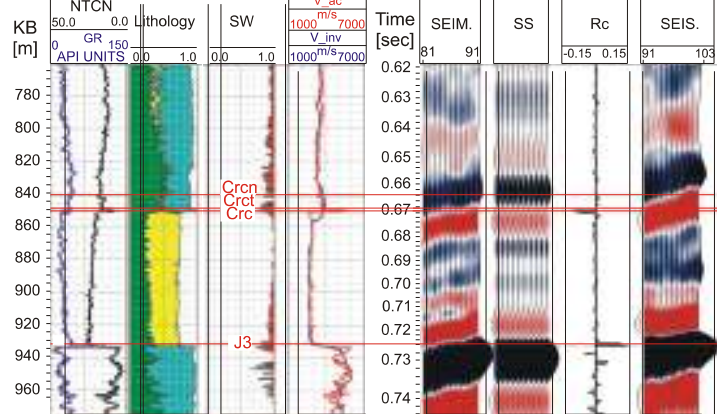

E

R1

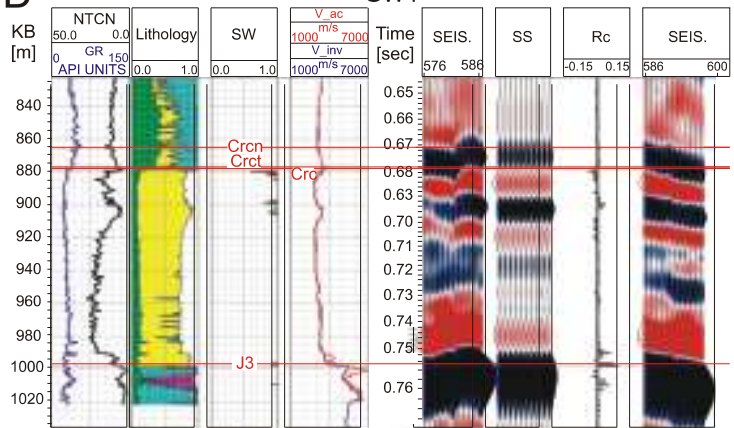

KB

F

Ryl5

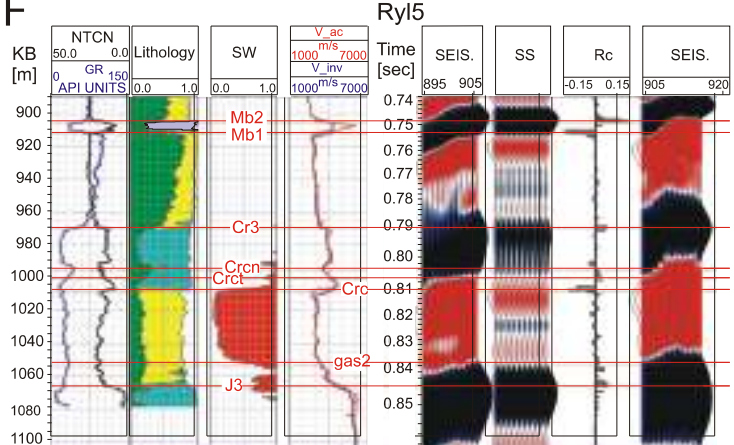

G
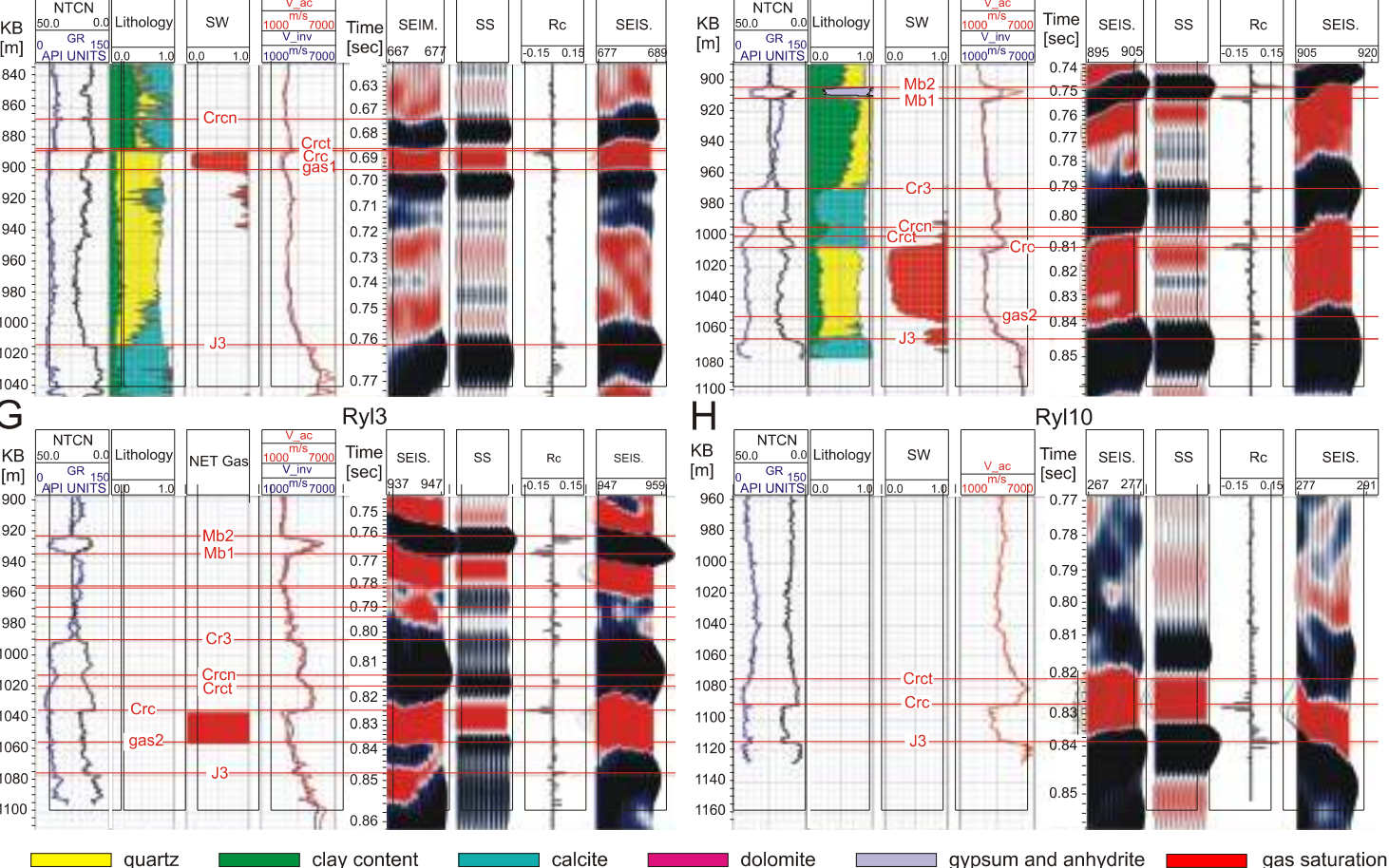

Fig. 11. Criteria for interpretation of the amplitude map for the top of the Cenomanian boundary in the area of the Rajsko reservoir and in the area of the Grobla Wschód 4 borehole based on model data (central part of the Grobla-Rajsko-Rylowa area)

A - seismic-geological model; $\mathbf{B}$ - synthetic data rotated by $270^{\circ}$ (wiggle traces) and data displaying instantaneous amplitude (colour); $\mathbf{C}$ - peak-to-trough amplitude plot before $(\mathrm{Cm})$ and after applying the transfer function $\mathrm{Cd}\left(f_{2}\right)$ for the top Cenomanian reflector $(\mathrm{Crc})$ based on synthetic data; $\mathbf{D}$ - peak-to-trough amplitude plot before $(\mathrm{Cm})$ and after applying the transfer function $\mathrm{Cd}\left(f_{2}\right)$ for the top Cenomanian reflector ( $\mathrm{Crc}$ ) based on real data; $\mathbf{E}$ - part of seismic section arbitrary line 1 which corresponds to the seismic-geological model (Fig. 10A) after phase rotation by $270^{\circ}$ 
A

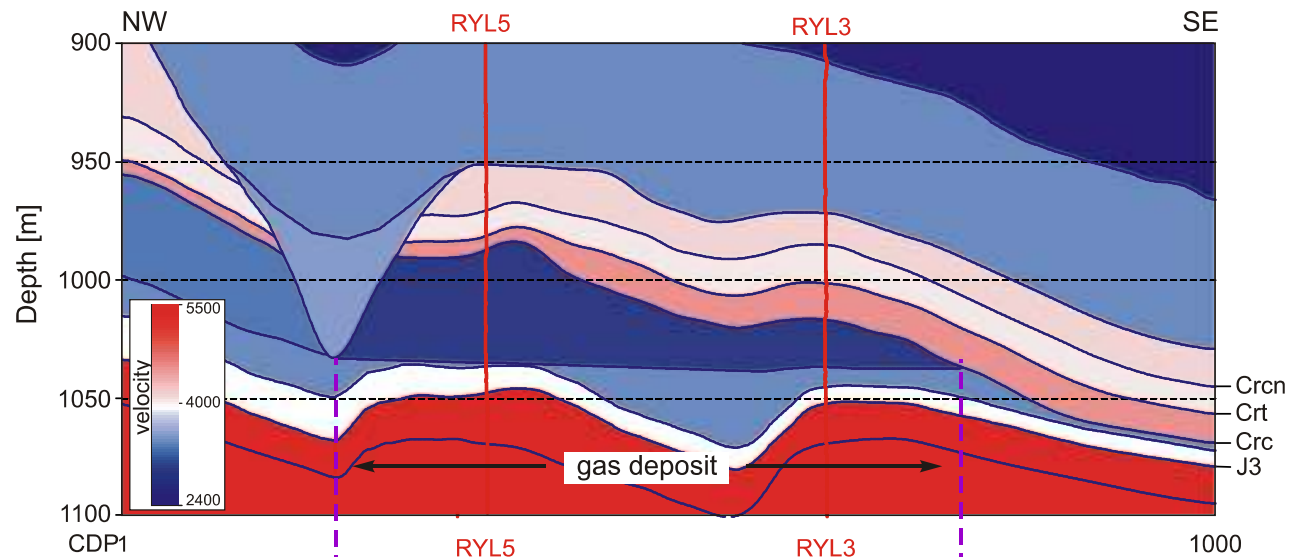

B

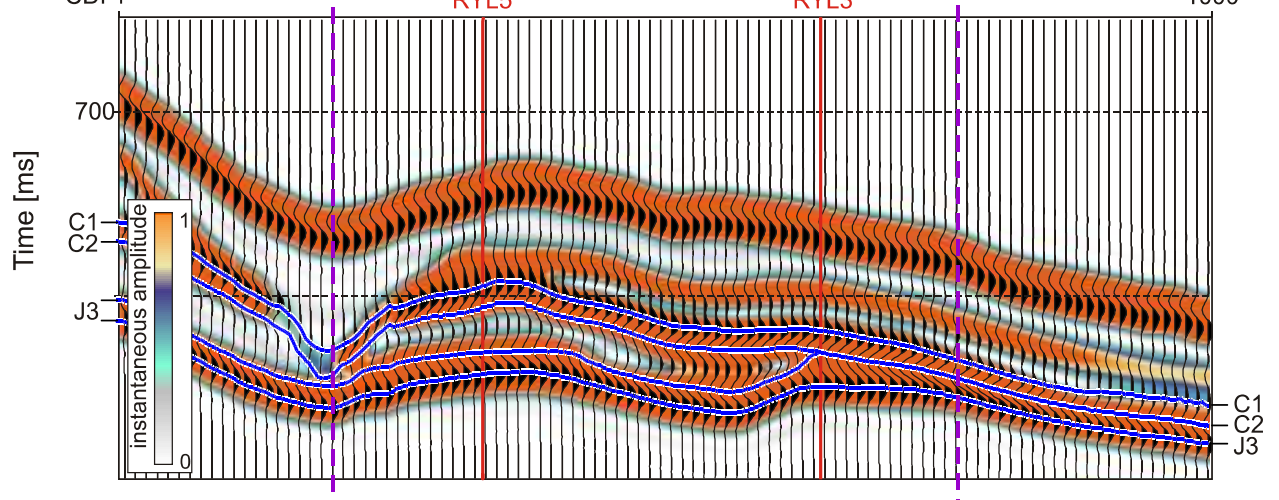

C

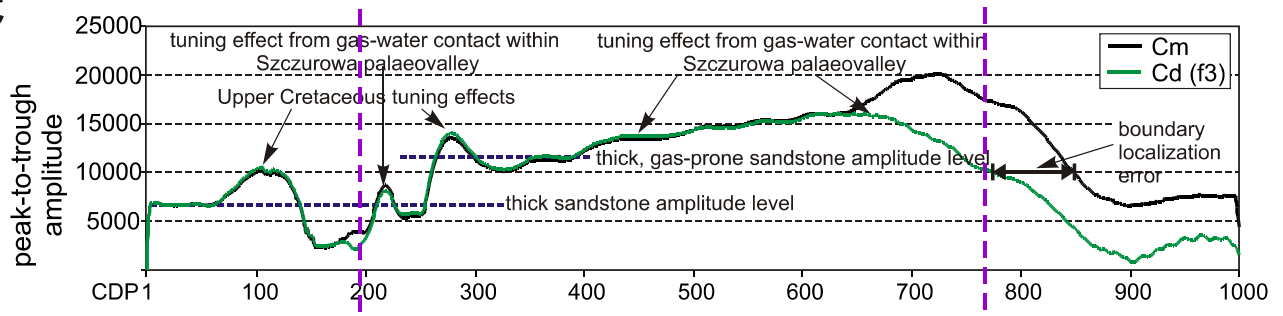

D

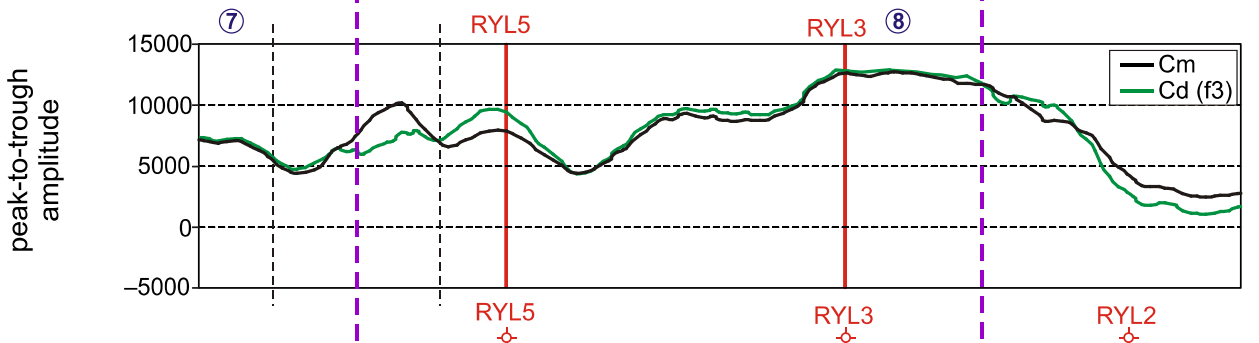

$E$

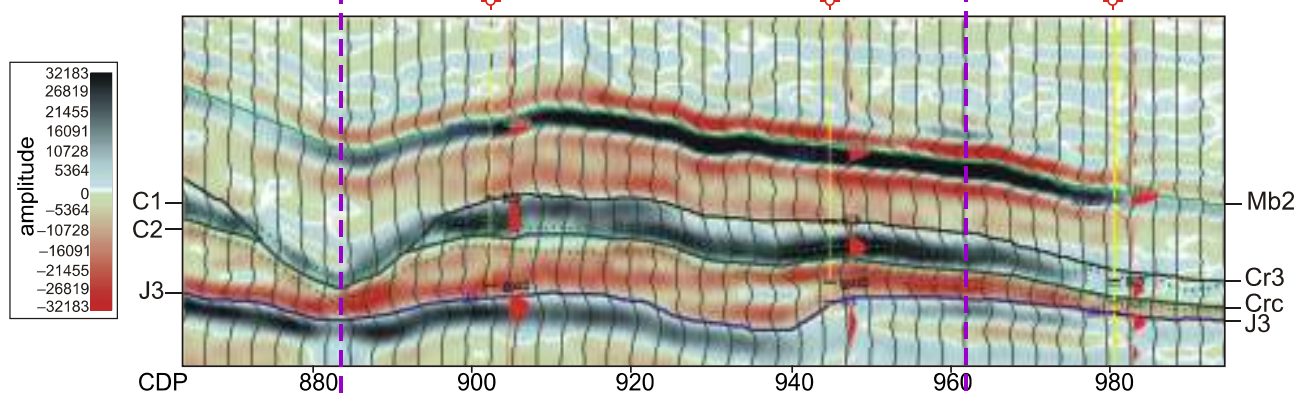

Fig. 12. Criteria for interpretation of the amplitude map for the top of the Cenomanian in the area of the Rylowa reservoir and the Szczurowa palaeovalley based on model data (eastern part of the Grobla-Rajsko-Rylowa area)

A - seismic-geological model; B - synthetic data rotated by $270^{\circ}$ (wiggle traces) and data displaying instantaneous amplitude (colour); $\mathbf{C}$ - peak-to-trough amplitude plot before $(\mathrm{Cm})$ and after applying the transfer function $\mathrm{Cd}\left(f_{3}\right)$ for the top Cenomanian reflector ( $\mathrm{Crc}$ ) based on synthetic data; $\mathbf{D}$ - peak-to-trough amplitude plot before $(\mathrm{Cm})$ and after applying the transfer function $\mathrm{Cd}\left(f_{3}\right)$ for the top Cenomanian reflector $(\mathrm{Crc})$ based on real data; $\mathbf{E}$ - part of seismic section arbitrary line 1 which corresponds to the seismic-geological model (Fig. 11A) after phase rotation by $270^{\circ}$ 
thickness of the gas-bearing zone is greater than the resolution of the seismic data, the increase in the amplitude coincides with the increase of the Turonian thickness. The increase in the amplitude $\mathrm{Cm}$ in the area of the Rylowa 5 borehole and on the opposite side of the palaeovalley can be explained by the tuning effect due to the palaeovalley incision and the associated sudden reduction in thickness of the Cretaceous succession. The tuning effect, which is a result of interference between the reflected signals from the top and bottom of the gas-saturated zone, is observed in the palaeovalley area and to the east of the Rylowa 3 borehole where the reflections from the water/gas interface are superimposed on reflections from the top and bottom of the Cenomanian and the top of the Turonian.

The transfer function $f_{3}$ applied to the synthetic data significantly lowers the amplitude of signal associated with a thin-bed reservoir or a thin zone of gas saturation. As a result, the error in estimating the reservoir boundaries based on the amplitude strength $\operatorname{Cd}\left(f_{3}\right)$ is reduced. The results of modelling indicate that interpretation of seismic data from the area of the Rylowa reservoir as well as other potential reservoirs of similar structural character may be difficult because the interpretation criteria have a local character.

Based on the analogy with the results of the model data, it can be assumed that the high amplitude, observed in zone no. 7 (Fig. 12D, E) and associated with the western margin of the palaeovalley, is caused by the pinch-out of the high velocity Turonin and Senonian deposits. Because of this, the interference of the event from the base of the Miocene (positive events) and the top of the Cenomanian (negative event).
The maximum value of the peak-to-trough amplitude in this zone is significantly lower than in the similar settings on the other side of the palaeovalley, which is associated with the Rylowa reservoir (Figs. 3B and 12D, E; anomaly no. 8).

\section{ANALYSIS AND INTERPRETATION MAP OF THE AMPLITUDE ALONG THE TOP OF THE CENOMANIAN}

The criteria for seismic interpretation, developed using results of seismic modelling and borehole data, were applied in analysis of the top of the Cenomanian seismic horizon interpreted across the entire 3-D volume. The results of the analysis are shown as four horizon maps. The peak-to-trough amplitude map for the top of the Cenomanian (Fig. 13), constructed using rotated seismic data, shows an image of anomalous areas which resemble the one shown on the instantaneous amplitude map (Fig. 3A). Despite applying smoothing filters, it is associated with a wider dynamic range. An example of this could be the area of the Rylowa reservoir where the instantaneous amplitude map shows an extensive high-amplitude anomaly which continues from the Rylowa 4 borehole towards the north-west to the Rylowa 5 borehole. The map of peak-to-trough amplitude shows that this zone is clearly nonuniform in terms of amplitude with a clear maximum to the north-east of the Rylowa 3 borehole. Apart from zones associated with the strongest anomalies of the Rajsko and Rylowa fields, there are a number of more or less extensive anomalies

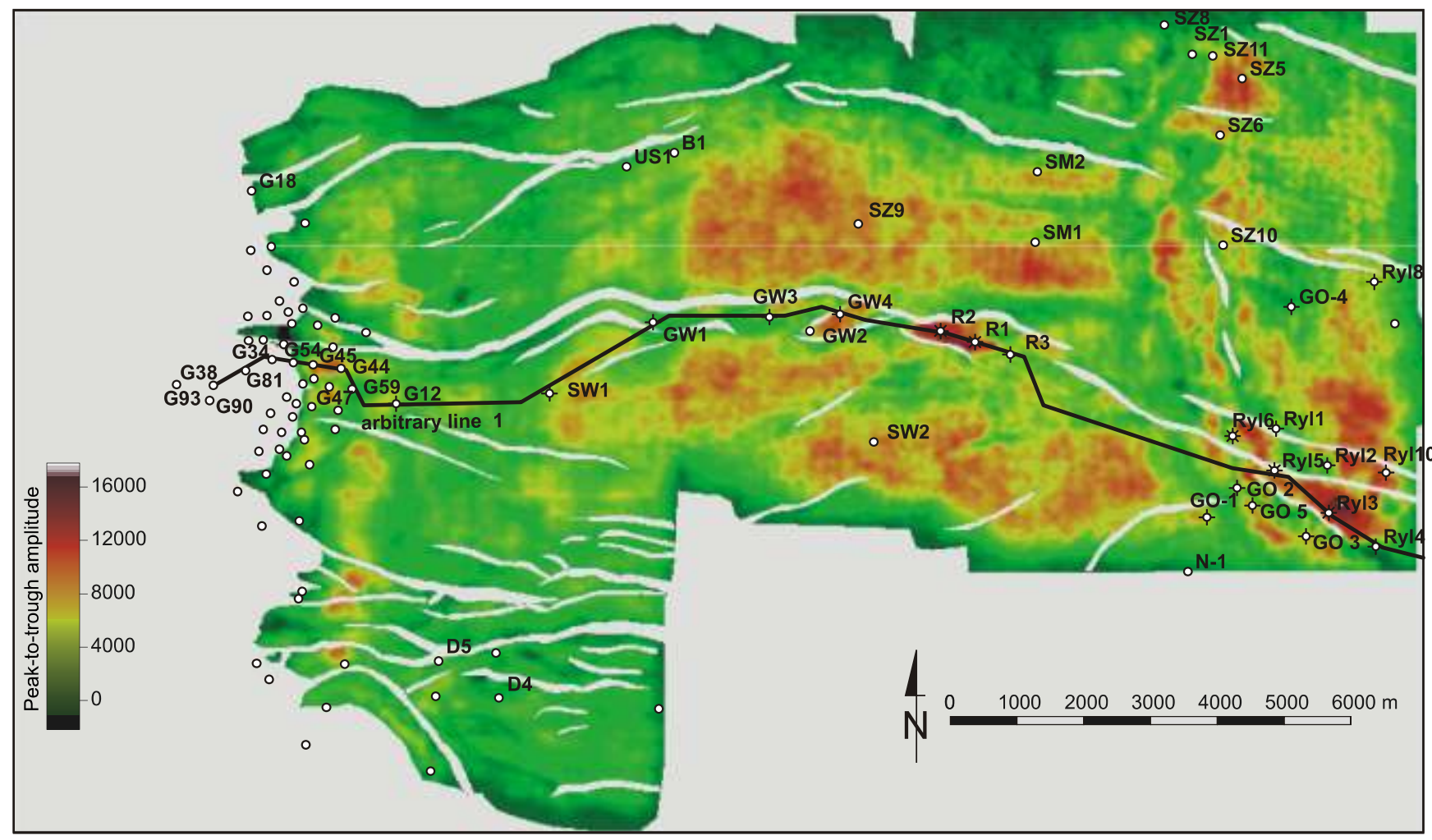

Fig. 13. Peak-to-trough amplitude map $\mathrm{Cm}$ for the top of the Cenomanian 


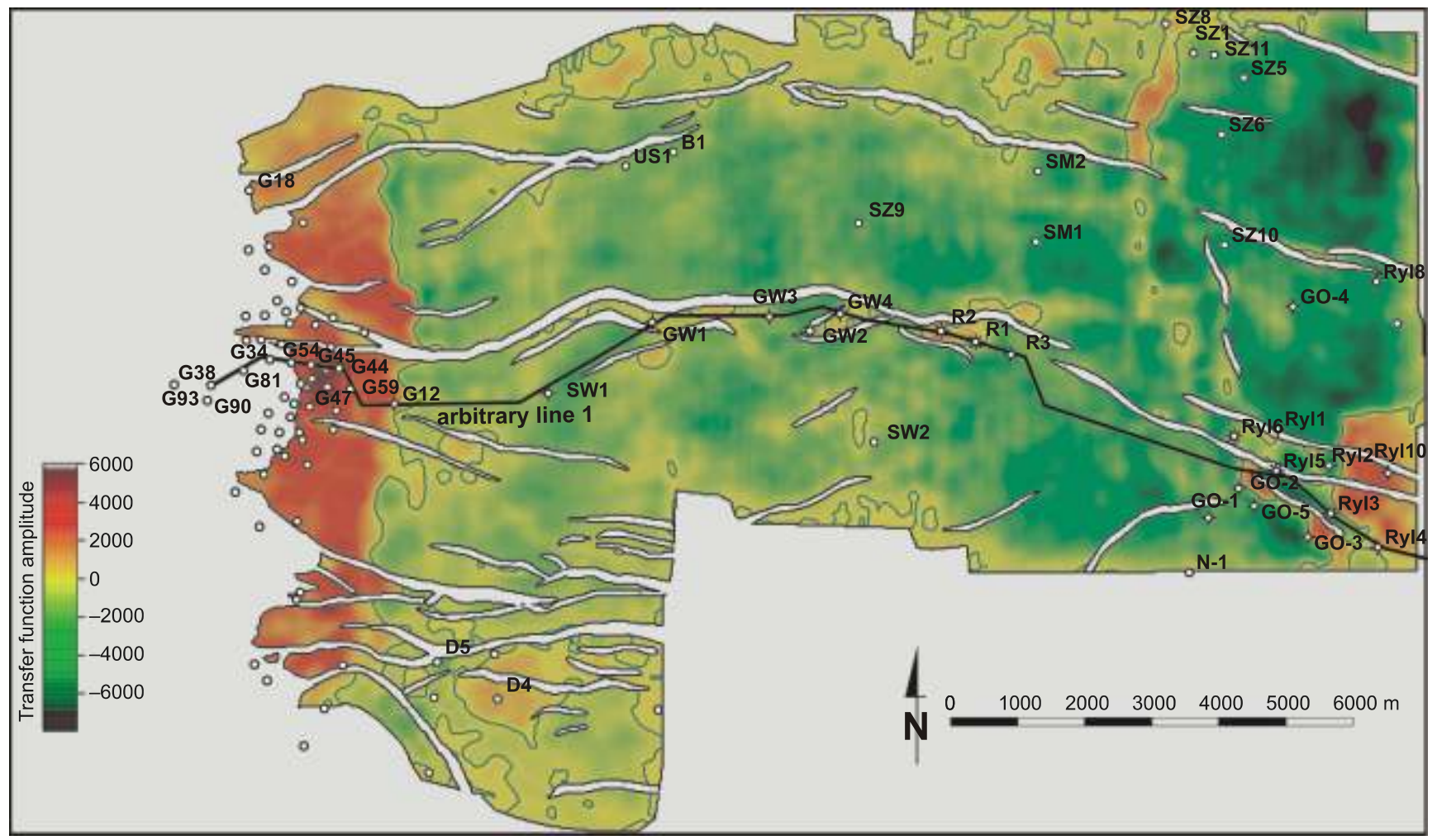

Fig. 14. Map showing the transfer function values $f_{2}$ with the zero-amplitude contour line

with variable strength of the maximum amplitude. Their origin is revealed by the transfer function $f_{2}$ map (Fig. 14) based on the total amplitude values (Fig. 6) along the top of the Cenomanian. Based on the modelling results, the positive $f_{2}$ values (warm colours) indicate the presence of a boundary with high positive reflection coefficient ratio within the interference zone beneath the Crc.

Strong positive anomalies (transition between red and brown) indicate interference between the reflections from the top Jurassic reflector and the top of the Cenomanian stratum where its thickness is less than $25 \mathrm{~m}$. Such conditions are present in the zone of the pinch-out of the Cenomanian stratum in the western and southeastern part of the dataset as well as locally along the along the axis of Szczurowa palaeovalley. In the central part of the study area the positive and close-to-zero $f_{2}$ values (marked yellow) are locally present across limited areas. These areas usually do not correspond to locally higher peak-to-trough amplitudes. The only exceptions are the areas of the Rajsko field and the Grobla Wschód 2 and 3 boreholes. In the majority of the study area, negative values of the transfer function (green) are observed, and the values decrease towards the east. The results of seismic modelling (Fig. 10) and borehole observations (Fig. 4) indicate that this effect is due to an increase in the thickness of the Turonian or an increase in the seismic velocity within the bottom part of the Senonian succession. In this area within the top part of the Cenomanian, only a gas-saturated zone could be present characterized by a thick- ness much smaller than the total thickness of the high-velocity formations overlying the Cenomanian. Where the gas-bearing zone is thicker, the geometrical relations between the strata counterbalance each other, and the values of the transfer function approach zero (Fig. 11B, C). Therefore, areas associated with transfer function values lower than -1600 (Fig. 14) were excluded from further analysis (Fig. 15, areas marked grey). The value of $f_{2}=-1600$ is present where the thickness of the gas-bearing zone is about $1 \mathrm{~m}$ in the model of the Rajsko field (Fig. 11A).

The map showing expected amplitude $\mathrm{Cd}\left(f_{2}\right)$ (Fig. 16) is the final result of the interpretation procedure carried out. As a result of applying the transfer function $f_{2}$, the amplitude anomalies in the central part of the study area are reduced or removed. The only exception is the amplitude anomaly associated with the Rajsko reservoir. In the thinning part of the Cenomanian succession near Grobla, the level of the maximum amplitude values is comparable with those from the area of the "thick" Cenomanian. The level of maximum amplitudes within the pinch-out zone of the Cenomanian in the Grobla zone more less corresponds to the level of average amplitude of the "thick" Cenomanian. It indicates the lack of feasible gas accumulations. This result supports the conclusions drawn from the analysis of the tuning curve (Fig. 5). Areas associated with negative values of amplitude indicate an increase in the seismic velocity within the Cenomanian rocks. This is supported by correlation with areas of higher inverse 


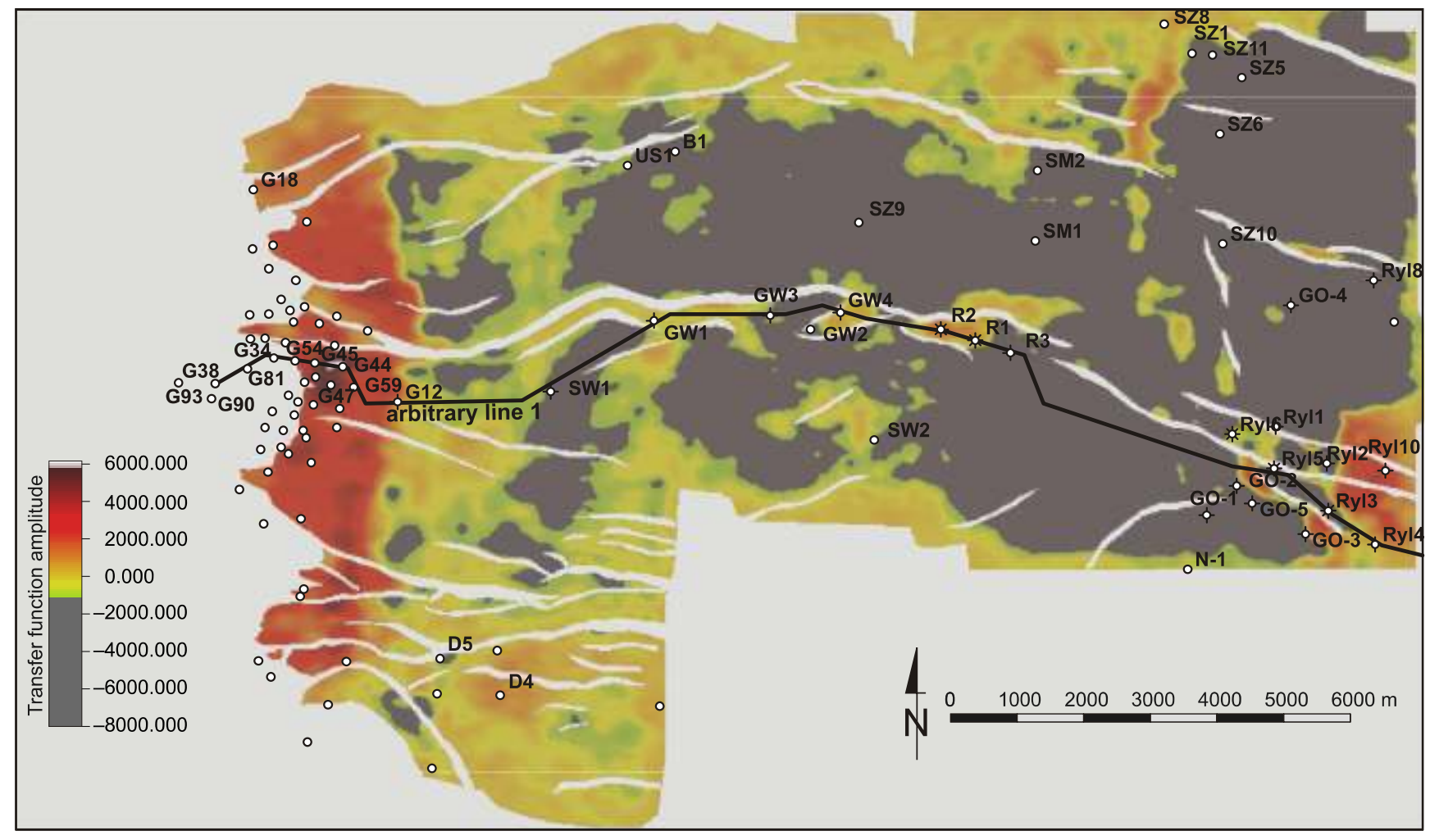

Fig. 15. Reinterpretation of the map showing the transfer function values $f_{2}$ for determination of the boundaries of the area where high values of peak-to-trough amplitude $\mathrm{Cm}$ correspond with the increase in thickness of the Turonian and/or increased velocity in the bottom part of the Senonian

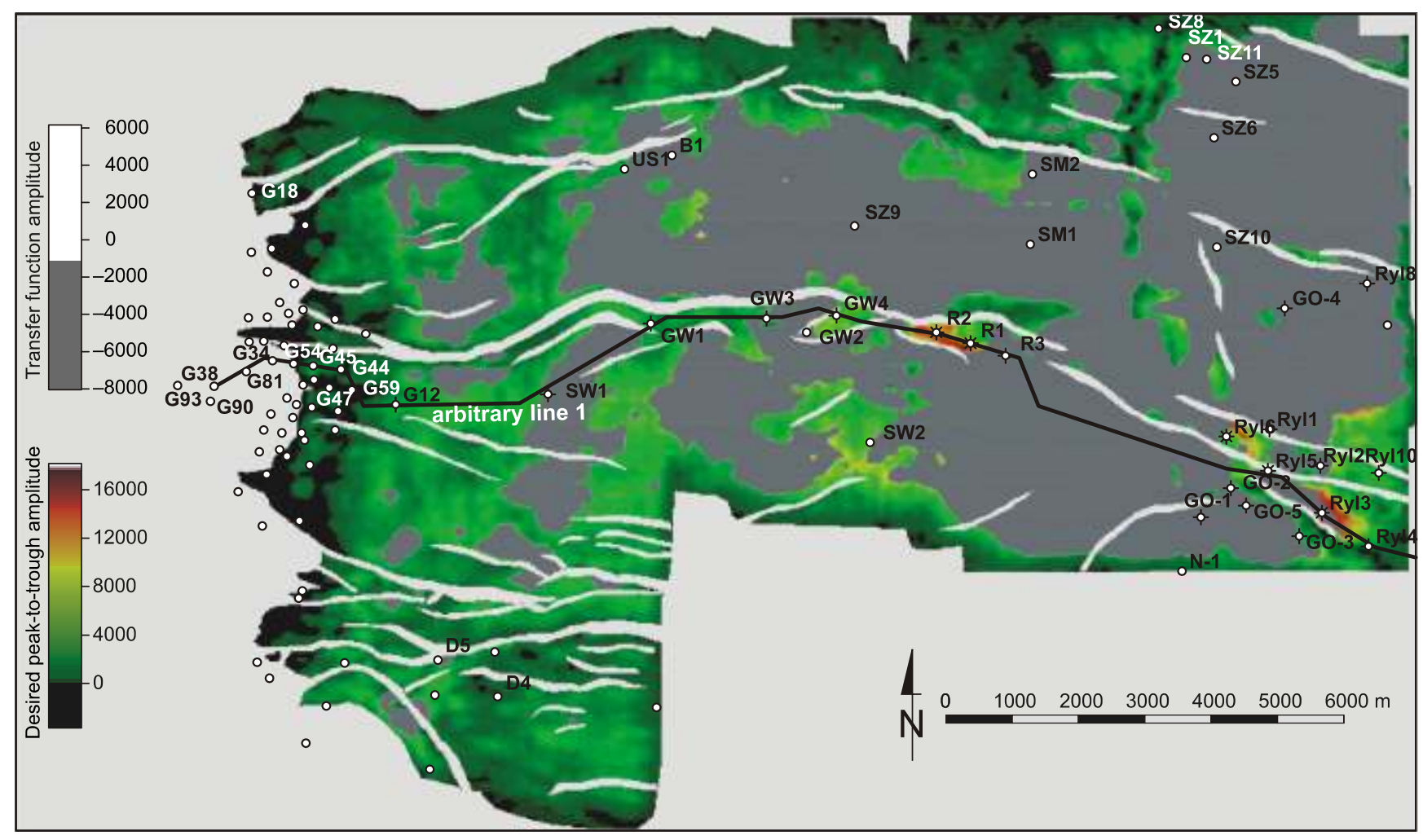

Fig. 16. Peak-to-trough amplitude map $\operatorname{Cd}\left(f_{2}\right)$ for the top of the Cenomanian after removing the tuning effect, and boundaries of the area determined based on distribution of the transfer function $f_{2}$ (Fig. 14) 
velocity (Marzec, 2009). After the removal of the high amplitude, associated with the interference with the reflections from the top of the Jurassic, the anomaly in the Rylowa reservoir area is more restricted and better corresponds with the reservoir boundaries (Karnkowski, 1999). It is limited to the north and south-east by tectonic boundaries, therefore no tuning effect is observed here. Other anomalies, such as those to the east and north of the Rylowa 2 borehole, were removed. From the exploration point of view, only the high amplitude anomaly located to the east of producing borehole Rylowa 6 is a prospective one. Here, the situation is similar to that in the Rylowa 3 borehole and the area to the east of it.

\section{CONCLUSIONS}

A need arose to develop an interpretative procedure to enable distinguishing amplitude anomalies related to saturation with gas from those related to positive signal interference reflected from thin-bedded strata (tuning zones). The procedure addresses a significant problem in the seismic interpretation of reservoirs, because the interpretation is mainly based on analysis of direct hydrocarbon indicators (DHI), that are mostly derived from amplitude anomalies characteristic of gas saturated zones.

The presence of such anomalies at the top of Canomanian sandstone within the Grobla, Rajsko and Rylowa oil and gas reservoirs was the reason for undertaking the research. The proposed method of identification and removing of the effect of amplitude amplified by interference of top and floor of the pinching-out bed is based on seismic data rotated by 270 degrees. Criteria for interpretation of rotated data were further developed from seismic modelling, and are established on the difference carried by peak-to-trough amplitude and total amplitude of the rotated seismic events. This difference allowed definition of the transfer function and, further, for removal of the effect of amplitude amplification within zones of tuning. The final product of the procedure developed is a chart showing the amplitude of seismic events from the top of the Cenomanian cleared of geometrical amplification related to the tuning phenomenon.

The method, and the criteria defined by modelling, were applied in analysis of the seismic event from the top of the Cenomanian provided in the 3-D Grobla-Uście Solne and Grobla Wschód-Rylowa survey and facilitated:

- more reliable contouring of the Rajsko and Rylowa reservoirs;

- extension of the reservoir zone at Rylowa east of the Rylowa 6 borehole;

- discarding the hypothesis of gas saturation within the zone of Cenomanian sandstone pinch-out over Jurassic beds (western and southeastern parts of the study area). The amplitude variations recorded within this zone are caused by changes of petrophysical parameters observable along transition from porous sandstone facies into an less porous and into an almost impermeable conglomerate;

- recognition of the non-reservoir origin of amplitude anomalies recorded across the greater larger part of the study area e.g.: between the Strzelce Wielkie 1-Grobla Wschód 1 and 3-Grobla Wschód 4 boreholes, as well as along the erosional trough of the Szczurowa palaeovalley. The anomalies are caused by thickness variations of high velocity intercalations both in overlying strata and in the Cenomanian

The interpretative procedure developed is mathematically uncomplicated and provides surprisingly good results. It tests utilization of changes of the signal within the tuning zone in removing the anomalies related to geometrical amplification from the amplitude maps. It can be used directly for reservoir identification as part of the existing system of seismic interpretation.

Acknowledgements. The authors of the paper express their gratitude to the Polish Oil and Gas Company PGNiG SA for their consent to use the data. The journal reviewers P. Brettwood and P. Krzywiec are thanked for helpful remarks.

\section{REFERENCES}

BARAN U., GLINIAK E., JAWOR E. and URBANIEC A. (1999) Perspektywiczność kompleksu górnej jury w rejonie Bochnia-Dębica w świetle badań sejsmicznych i wyników geologiczno zło owych. Nauka i Przemysł w XXI wieku: 85-94.

BROWN A.R., WRIGHT R.M., BURKHARD K.D., ABRIEL W.L. and McBEEATH R.G. (1986) - Tuning effects, lithological effects and depositional effects in the seismic response of gas reservoirs. Geophys. Prosp., 34: 623-647.

CONNOLLY P. (2007) - A simple, robust algorithm for seismic net pay estimation. The Leading Edge, 26 (10): 278-282.

FLOREK R., GÓRKA A. and ZACHARSKI J. (2002) - Generation and accumulation of hydrocarbons in Meso-Paleozoic structures of Carpathian Foreland - case studies of Grobla-Strzelce Wielkie-Rajsko (in Polish with English summary). Pr. Inst. Gór. Naft. i Gazow., 116: 39-43.
FLOREK R., GÓRKA A. and ZACHARSKI J. (2006) - Wpływ architektury mezo-paleozoicznego podło a miocenu na warunki migracji i akumulacji węglowodorów w utworach cenomanu i części przedgórza Karpat. Pr. Inst. Gór. Naft. i Gazow., 137: 231-239.

JAWOR E. (1973) - Deposits conditions of the Grobla-Pławowice Zone in the background of deep tectonics of the area eastwards of Cracow (in Polish with English summary). Pr. Geol. PAN, 81.

JAWOR E., JAWOR W. and BARAN U. (1997) - Rozwój piaskowców cenomanu w obszarze zapadliska przedkarpackiego i warunki występowania akumulacji węglowodorów. Rozwój polskiej myliśli w poszukiwaniach naftowych: 269-273.

KALLWEIT R.S. and WOOD L.C. (1982) - The limit of resolution of zero-phase wavelets. Geophysics, 47: 1035-1046.

KARNKOWSKI P. (1999) - Oil and Gas Deposits in Poland. Towarzystwo Geosynoptyków „Geos”, AGH, Kraków. 
MARZEC P. (2004) - An attempt to eliminate amplitude gains caused by tuning from a map of seismic reflexes from the Cenomanian sandstone in the Grobla oil and gas field. Pol. J. Miner. Res., 8 P: 161-172.

MARZEC P. (2009) - Geologiczna interpretacja zapisu sejsmicznego rejestrowanego dla układów cienkowarstwowych. Ph.D. thesis Biblioteka Główna AGH, Kraków.

OSZCZYPKO N. and ŚLĄCZKA A. (1989) - The evolution of the Miocene basin in the Polish Outer Carpathians and their foreland. Geol. Carpath., 40: 23-36.

OSZCZYPKO N., KRZYWIEC P., POPADYUK I. and PERYT T. (2006) Carpathian Foredeep Basin (Poland and Ukraine) - its sedimentary, structural and geodynamic evolution. AAPG Mem., 84: 293-350.

PIETSCH K. and MARZEC P. (2003) - Amplitude analysis as the tool for identifying seismic anomalies generated by tuning (in Polish with English summary). Geologia, 29 (1-2): 89-101.
PIETSCH K., MARZEC P., TATARATA A. and KOBYLARSKI M. (2005)

- Analiza zmienności sygnału sejsmicznego w strefie Grobla Okulice-Rajsko pod kątem określenia obiektów do poszukiwań (Unpublished report). Praca Naukowo Badawcza Departamentu Poszukiwania Złó . PGNiG S.A. CRZ: 2005/03/000051/OC.

WIDESS M.B. (1973) - How thin is a thin bed. Geophysics, 38 (6): 1176-1180.

ZENG H. and BACKUS M.M. (2005a) - Interpretive advantages of $90^{\circ}$ phase wavelets: Part 1 - Modeling. Geophysics, 70: 7-15.

ZENG H. and BACKUS M.M. (2005b) - Interpretive advantages of $90^{\circ}$ phase wavelets: Part 2 - Seismic applications. Geophysics, 70: 17-24. 